\title{
LAS IMÁGENES EN LA CULTURA POLÍTICA LIBERAL DURANTE EL TRIENIO (1820-1823): EL CASO DE BARCELONA
}

\author{
Jordi ROCA VERNET \\ (Universitat Autònoma de Barcelona)
}

Aceptado: 16-XII-2002

RESUMEN: La imagen es un elemento clave en la conformación del discurso político liberal, capaz de penetrar en las clases más populares y difundir entre ellas los principios más universales del liberalismo. La facilidad de acceso al mundo visual permite a los grupos sociales más desfavorecidos apropiarse de un mundo ideológico nuevo. Las ideas del liberalismo son redefinidas y reinterpretadas por distintos grupos ante la necesidad política de buscar unas alternativas y unos proyectos al margen de los determinados por los grupos liberales dirigentes. La imagen del liberalismo es la parte más sugerente del discurso, observamos cómo está fuertemente condicionada por la influencia francesa, la cual no se circunscribe a los determinantes provenientes de la Revolución, sino que va más allá y se apropia de símbolos de la era napoleónica. Palabras clave: Imagen política, discurso liberal, liberalismo español, Trienio Liberal, cultura visual liberal, Barcelona.

ABSTRACT: Picture is a key element in building the liberal political speech, being capable of penetrating inside the most popular classes and to diffuse among them the most universal principles of Liberalism. The visual world's easy-access feature let the most underprivileged social groups to become owners of a new ideological frame. Faced the political need of searching choices as well as new schemes apart from leader liberal groups liberalism's ideas are repeatly defined and interpreted again by the several groups. Liberalism picture is the most suggesting point of the speech, as we notice how it's strongly conditioned by French influence, which is not confined to determinants provided by Revolution, but it goes over appropriating the symbols of Napoleonic times. Keywords: Political picture, political liberalism speech, Spanish liberalism, Trienio Liberal, liberal visual culture, Barcelona.

La imagen es un documento histórico frecuentemente despreciado por la historiografía. En la era de los efectos visuales no podemos continuar manteniendo en el ostracismo la imagen como fuente histórica. La iconografía resulta esencial para comprender cuáles y cómo eran los mecanismos de transmisión de ideas y valores entre los distintos 
grupos sociales, profundizando de este modo en las relaciones que se establecían entre la cultura popular y la cultura de la elite o dominante. A través de la imagen podemos analizar cuál era el grado de politización de los estratos populares de la sociedad, cómo los sectores más bajos percibían las nuevas ideas liberales y si algunos grupos fueron capaces de generar proyectos políticos alternativos a partir de los nuevos conceptos. La extensión de la difusión de imágenes de temática política entre la población contribuyó a la desacralización de la política, permitiendo que la sociedad abriera un debate sobre cuál era la mejor forma de gobierno. La popularización de la discusión política sobre el régimen de gobierno posibilitó el acceso a la cultura política de una gran parte de la población que hasta ese momento había sido marginada. El liberalismo era el responsable del cuestionamiento del orden político imperante y aprovechó la oportunidad para presentarse como una alternativa política para el conjunto de la sociedad. La ideología liberal por su carácter universal y su percepción de una sociedad sin clases permitía concebir ilusiones a sectores sociales que iban más allá de los propios grupos burgueses, consiguiendo de esta forma que el discurso liberal arrastrara amplios sectores de la población. ${ }^{1}$

El liberalismo recurrió a la creación de nuevos referentes simbólicos para acercar sus ideas a la sociedad española. La historiografía ha infravalorado todo el elenco simbólíco que generó y desplegó el liberalismo. Las imágenes producidas por el liberalismo, como sucedió con el lenguaje textual liberal, tuvieron múltiples lecturas. Debemos alejarnos de interpretaciones unívocas del mundo visual y sumergirnos en las distintas interpretaciones que los espectadores generaron alrededor de ellas. Los ciudadanos reelaboraron el lenguaje visual continuamente, dotando al liberalismo español de un discurso político de gran riqueza que traslucía todos los referentes comunes de los liberales, a la vez que explicitaba las diferencias entre diversos grupos ideológicos.

La historiadora María Cruz Romeo resalta la potencialidad revolucionaria del liberalismo, al ser esta una ideología basada en una sociedad de ciudadanos que se oponía a toda restricción de la libertad del individuo, siendo por lo tanto un proyecto potencialmente igualitario y atractivo para una diversidad de clases y capas sociales. Los símbolos y mitos del liberalismo se convirtieron en fuerza cohesionadora para la sociedad liberal. La historiografía ha aceptado «la posibilidad de que haya elementos de la cultura de las clases subordinadas, que se desarrollen de modo autónomo a partir de la cultura de las clases dominantes, cuyo efecto sea una reducción de las actividades

\footnotetext{
' Romeo Mateo, María Cruz: Entre el orden y la revolución. La formación de la burguesía liberal en la crisis de la monarquía absoluta (1814-1833), Colección «Ensayo e Investigación», Instituto de Cultura "Juan Gil-Albert», Alicante, 1993, p. 95.
} 
de oposición. Esto, sin embargo, no se debe tomar erróneamente por una integración

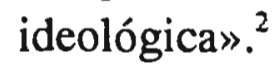

La historia del liberalismo español es una fuente insaciable de acontecimientos donde es posible contemplar las distintas percepciones de los principios liberales desde el mundo popular. La lectura radical de los ejes del liberalismo implicaba la destrucción del orden social imperante, a la vez que desarrollaba la gestación de proyectos políticos alternativos, que se alejaban de las directrices propugnadas por las autoridades liberales. Varios serán los ejemplos que citaremos a continuación para ratificar la creación de un discurso político no sujeto al direccionismo de las clases dirigentes:-En 1820, un grupo de liberales radicales asaltó los palcos del Teatro Principal de Barcelona, vociferando a favor de la Igualdad. ${ }^{3}$-En el año 1822, un liberal moderado como Selta Rúnega, pseudónimo de Francisco Altés, consideraba que hombres y mujeres debían ocupar los mismos asientos en el teatro y en las tribunas de la ciudad condal, esa opinión la expuso en el Diario Constitucional Politico y Mercantil de Barcelona y fue legitimada por el eco que obtuvo la propuesta. Otro periódico barcelonés, Diario de la Ciudad de Barcelona o Eco de la Ley, pocos días después sancionaba y establecía una definición de igualdad, tomando como ejemplo la propuesta de Altés. ${ }^{4}$

A lo largo de todo el Trienio, el liberalismo construyó una galería de referentes visuales. Su comprensión distó mucho de ser la misma para todo el mundo. Las diferencias en la recepción del lenguaje visual generaron y ensancharon las divergencias en el seno del liberalismo, materializadas en la creación de nuevos discursos a partir de unos mismos referentes simbólicos. A continuación, nos adentramos en el estudio de varios aspectos relevantes del mundo simbólico liberal, para observar cómo se materializaron esas divergencias.

\section{La muerte del héroe y el nacimiento del mártir.}

El Trienio liberal (1820-1823) fueron unos años de gran actividad en la construcción de mitos para el liberalismo. La configuración de la galería de mártires, es decir, el martirologio fue esencial en la representación iconográfica del liberalismo. Conviene hacer algunas distinciones entre los mártires liberales para catalogarlos de manera adecuada. Habremos de diferenciar entre aquellos individuos que fueron extraídos de una relectura de la historia de los reinos hispanos y los que fueron víctimas del enfrenta-

2 Ídem, p. 99.

${ }^{3}$ Arnabat Mata, Ramon: La revolució de 1820 i el Trienni liberal, Editorial Eumo, Vic, 2001, p. 33.

${ }^{4}$ Diario de la Ciudad de Barcelona, $\mathrm{n}^{\circ} 188,10$ de diciembre de 1822, p. 516: «Gacetín (...) Igualdad: Tiene muchísima razón el señor Selta Rúnega en su artículo inserto ayer en el diario de las indulgencias que es faltar a ella no permitiéndose a las señoras mujeres ocupar los asientos del patio y si sólo lunetas». 
miento con el absolutismo fernandino; a los primeros los hemos denominado liberales históricos mientras que a los segundos, simplemente, liberales. En estas categorías distinguiremos entre mártires individuales y colectivos.

Comparando los héroes fundadores del movimiento revolucionario francés con los de la Revolución Liberal española podemos obtener valiosísimas conclusiones. En Francia, los mártires fundadores de la Revolución fueron Rousseau y Voltaire, ${ }^{5}$ ambos insignes filósofos o elucubradores de ideas. La elección de estos dos individuos respondía a la necesidad de hacer un reconocimiento público a los generadores de las ideas que habían destruido el despotismo, convirtiéndoles en los auténticos artífices del cambio. Sus ideas estaban en el punto de partida del nacimiento de un mundo nuevo, en nada parecido a todo lo anterior, por lo tanto era inútil rebuscar en el pasado. Todo lo contrario sucedió en España, donde los revolucionarios intentaron hilvanar la Revolución Liberal con casi todos los movimientos de protesta que se produjeron contra la dinastía de los Austrias. El héroe del liberalismo español no era un creador de ideas como había sucedido en Francia, sino el individuo que se sublevaba contra la tiranía y luchaba sin desfallecer con la fuerza de las armas por sus principios, llegando si cabe a sacrificar su vida si con ello podía hacer triunfar sus ideas. Era el desarrollo incipiente del culto de la acción vehemente individual o colectiva en detrimento del culto al raciocinio, a las ideas, en definitiva un acercamiento al mundo romántico, ${ }^{6}$ que se estaba gestando en Europa. Los mártires históricos del liberalismo se habían forjado en los campos de batalla y no entre libros. Eran individuos venerados no por sus ideas sino por cómo habían luchado hasta la muerte para defenderlas. La lucha de todos ellos se consagraba a la libertad y contra la tiranía.

El elenco de liberales históricos estaba configurado:-Por los Comuneros, básicamente el triunvirato Bravo, Padilla y Maldonado, éstos eran los rebeldes castellanos que se sublevaron contra el primero de los monarcas de la dinastía de los Austrias, Carlos I, en 1521. -También, por los Insurrectos Aragoneses, entre los más destacados cabe citar a Lanuza, De Heredia y De Luna; todos ellos se enfrentaron con Felipe II, en 1591. -Finalmente, por los Claris, ${ }^{7}$ nombre que hacía referencia en Cataluña a los insurrectos

${ }^{5}$ Vovelle, Michel: La mentalidad revolucionaria, Editorial Crítica, Barcelona, 1989, p. 136.

${ }^{6}$ Indicador Catalán, $\mathrm{n}^{\circ} 122,2$ de mayo de 1823, p. 3: « ¡Genios sublimes! Los que primero abristeis a la patria la senda de la inmortalidad! Héroes del dos de mayo! Barcelona y la nación toda se acercan otra vez a vuestras tumbas, para tributaros admiración y gratitud. Ante vuestras cenizas juráremos de nuevo rechazar la tiranía. Con la memoria de vuestro sacrificio nos será dulce si conviene la muerte por la patria».

${ }^{7}$ La Voz del Pueblo, $\mathrm{n}^{\circ} 22,13$ de agosto de 1822: «José Cortés (...) Ya que por experiencia propia sabe lo que es quedarse en cueros, debe esperarse que se interesará para que a los demás liberales perjudicados por los bandidos, tengan o no terrenos, se les indemnize de lo que hayan sufrido con los bienes de los conspiradores facciosos, y que la justicia de esta pretensión está muy al alcance de nuestro diputado provincial aunque sea labrar porque está arreglado á los preceptos de la ley natural. Si no es hijo de Padilla es descendiente de los Claris y otros ilustres catalanes que lo sacrificaron todo por el bien de la patria». También encontramos 
catalanes que se revelaron contra Felipe IV, en 1640. Dicho nombre evocaba la figura del líder de los rebeldes catalanes, Pau Claris. A diferencia de Comuneros y Aragoneses, el culto de los héroes catalanes nunca llegó a institucionalizarse, aunque sí tuvo un seguimiento entre la población catalana, muy especialmente en el marco de la cultura popular.

Los cadáveres de Comuneros y Aragoneses fueron desenterrados con el objetivo de hacerlos recalar en «el panteón nacional», proyectado por Canga Argüelles, ${ }^{8}$ aunque dicho panteón nunca llegó a construirse. La elección de estos dos colectivos se hizo con la intención de conectar las dos tradiciones insurreccionales de la nación española, una proveniente de la corona castellana, y la otra de la corona catalano-aragonesa. Por lo tanto, la inclusión de los héroes catalanes se habría descartado porque podía producir una desestabilización en el equilibrio de ambas tradiciones.

$\mathrm{El}$ análisis no debemos ceñirlo a estos tres grupos, pues hay dos grupos que merecen mención aparte: -Es el caso de la no inclusión de los catalanes sublevados contra el monarca Felipe $\mathrm{V}$ a principios del siglo XVIII. Las razones de su omisión hemos de buscarlas en la voluntad de no deslegitimar la dinastía reinante en España. La glorificación de los insurrectos austracistas podía implicar el cuestionamiento de Fernando VII como heredero del monarca triunfador de la guerra de sucesión, Felipe V. -Los insurrectos madrileños del dos de mayo de 1808, fundamentalmente las figuras de Daoíz y Velarde. Ambos se enfrentaron a los franceses cuando estos ocuparon la península. Los cabecillas de la insurrección contra el invasor también tuvieron el honor de tener reservado un espacio en el nuevo panteón nacional. Para el caso catalán, podríamos incluir un referente más en la lucha contra el invasor francés, este era el caso de la popular figura del tamborilero del Bruc, rememorado en la portada de la obra de Robreño «Numancia de Cataluña y libre poble de Porrera», obra de teatro que fue la más representada en Barcelona durante el Trienio. ${ }^{9}$ La acción del héroe del Bruc fue recuperada para ilustrar la defensa acérrima de la villa de Porrera frente a las tropas realistas. ${ }^{10} \mathrm{La}$ figura del tamborilero la debemos comparar con los héroes niños nacidos durante la Revolución Francesa, como eran Bara y Viala. Su culto nunca llegó a los niveles de popularidad de Marat, Chalier o Lepeletier, pero por el contrario, se convirtió

referencias a Pau Claris en algunos edictos y bandos publicados por la Diputación de Cataluña durante el año 1821 (Vol. 17 fol. 181 del Archivo del Distrito de Barcelona, Sarrià-Sant Gervasi).

${ }^{8}$ Guereña, Jean Louis: «Fête Nationale, Fête populaire? Les premières commémorations du 2 Mai (18091833)», Aymes, Jean-René y Fernández Sebastián, Javier, La imagen de Francia en España (1808-1850), Servicio Editorial Universidad del País Vasco, 1995, p. 48.

${ }^{9}$ Arnabat Mata, Ramon: La revolució de 1820 ..., p. 156.

${ }^{10}$ La imagen a la que nos referimos aparece en Anguera, Pere i Milà, Joan: Lliure poble de Porrera, Ajuntament de Porrera, 1985, p. 109. 
en masivo entre el republicanismo francés de finales del siglo XIX. ${ }^{11}$ Es evidente que la manipulación del significado de los niños héroes podía ser mucho mayor, posibilitando la articulación de un discurso a la medida de las autoridades.

Con la etiqueta de mártires liberales designamos al colectivo de liberales muertos durante el Sexenio Absolutista y el Trienio Liberal como consecuencia de sus enfrentamientos con el despotismo. Todos ellos tienen en común haber muerto gloriosamente luchando por los principios de la libertad. Los grupos dominantes liberales fomentaron el culto a los individuos, quedando en un segundo plano el culto a los colectivos. El calado entre los sectores populares barceloneses del culto al individuo fue enorme, caso paradigmático de éste es el culto desarrollado a la figura de Lacy, en buena medida instigado por las autoridades liberal-moderadas de la ciudad. También habrá sitio para otras figuras que intentaron pronunciarse en los años del Sexenio, como eran Porlier, Sánchez Barbero, Vidal, entre otros... o para los militares liberales muertos en el pronunciamiento de 1820, como eran Acevedo y Tirado. Aunque, de ninguna manera su culto llegó a ensombrecer la figura de Lacy, no hay duda que esto se debe a la implicación de la sociedad catalana en el intento de pronunciamiento del Capitán General Lacy. Aquello que hizo entrar a estos individuos en la galería de mártires del liberalismo fue la glorificación de una muerte apoteósica, una concepción más cerca del culto clásico pagano que no de la tradición cristiana, ${ }^{12}$ explicable en parte por la eclosión de la nueva sensibilidad romántica ${ }^{13}$ que exaltaba por encima de todo la acción del individuo como elemento dinamizador del conjunto de la sociedad.

Así pues el culto al individuo y a sus acciones dejaba poco espacio para el culto a los colectivos. Fue principalmente en el mundo de la cultura popular liberal donde se desarrolló una devoción mayor hacia los mártires colectivos, siendo básicamente éstos dos:-Los Milicianos (y en menor medida los soldados) muertos en el campo de batalla. Las autoridades barcelonesas, indiferentemente de si éstas eran exaltados o moderados, siempre intentaron personalizar e individualizar los actos de conmemoración, sucediéndose a lo largo del Trienio multitud de funerales a los héroes caídos en la lucha contra los realistas. -El pueblo gaditano, asesinado como consecuencia de los hechos del 10 de marzo de 1820 , muy venerado entre los sectores populares barceloneses, como lo

${ }^{11}$ Vovelle, Michel: La mentalidad revolucionaria..., p. 139.

12 Ídem, p. 146.

${ }^{13}$ Butrón Prida, Gonzalo: «Fiesta y Revolución. Las celebraciones políticas en el Cádiz Liberal (1812-37)», en Gil Novales, Alberto, La Revolución liberal (Congreso sobre Revolucion Liberal Española en su diversidad peninsular (e insular) y Americana, abril 1999), Ediciones del Orto, Madrid, 2001. 
demuestra que apareciera mencionado en muchas hojas volantes del año $1821,{ }^{14}$ antes que las Cortes institucionalizaran el 10 de marzo como día de luto nacional.

Donde resultan más palpables las tensiones en el proceso de heroificación revolucionaria es en el mundo de los héroes vivos. Según Vovelle, ${ }^{15}$ la desconfianza respecto al héroe vivo hizo que se fomentara mucho más el héroe muerto, lo que nosotros hemos llamado el mártir. El Trienio es un momento de intensa creatividad simbólica y de construcción de héroes fruto de la confluencia de la cultura de la elite y de la popular. El surgimiento y desarrollo de un héroe es la mejor manera de observar cómo después de una comunión inicial entre distintos grupos sociales se produce el conflicto, el ejemplo más claro lo encontramos en la figura de Riego.

En efecto la representación más fidedigna del héroe liberal por antonomasia fue la de Riego. La popularidad de este héroe no tuvo parangón, siendo sin lugar a dudas el personaje más aclamado por las capas populares de la sociedad. Algunos historiadores ${ }^{16}$ han comparado el culto popular hacia Riego con la veneración popular de Marat en la Francia revolucionaria. No obstante, a pesar que la devoción hacia este héroe tuviera mayor arraigo entre los sectores populares hispanos, como lo demuestran la multitud de utensilios de todo tipo en los cuales aparecía su imagen, ${ }^{17}$ el héroe de la Francia revolucionaria al que más se le comparó fue a Napoleón. Europa, y particularmente Francia, vieron en Riego al redentor de los principios revolucionarios, consagrándolo como un nuevo Napoleón. Algunos franceses fueron más allá, extendiendo un rumor que situaba a Napoleón en España, donde reunía un ejército para combatir a los Borbones franceses y españoles. La eficacia y extensión del rumor ilusionó a las masas populares del país galo con el regreso del Emperador a principios de 1821 para liberarles de la monarquía borbónica. ${ }^{18}$ La veneración popular francesa hacia a Napoleón fue tal, que aún después de su muerte se creyó en su regreso a lo largo de la década de los años veinte. La irrupción de la figura de Riego en el mundo de política liberal europea favoreció la persistencia de la devoción popular en el regreso del Emperador. Las masas franceses

${ }^{14}$ Letania Constitucional, Barcelona: en la imprenta constitucional de Joaquin Jordi, calle de la librería, año 1821; y Coplas Patrióticas. En honor de los soldados veteranos y milicianos locales, por la restauración de la Constitución de la Monarquía, Barcelona: En la imprenta Constitucional de Joaquin Jordi, calle de la Libretería: año 1821.

${ }^{15}$ Vovelle, Michel: La mentalidad revolucionaria..., p. 138.

${ }^{16}$ Fuentes, J. F.: «Aproximación al vocabulario socio-político del primer liberalismo español (1792-1823)», en Aymes, Jean-René y Fernández Sebastián, Javier, La imagen de Francia en España (1808-1850), Servicio Editorial Universidad del País Vasco, 1995, p. 58.

${ }^{17}$ Astur, Eugenia: Riego, Principado de Asturias, Consejería de Educación, Cultura y Deportes. Vitoria, 1984, p. 413: «Aunque no dejaría por otra parte de agradarle esta adoración al General (Riego), cuya efigie andaba no sólo en medallones, abanicos y cajas de rapé, sino hasta en objetos de uso vulgar».

${ }^{18}$ Ménager, Bernard: Les Napoleón du peuple, Ed. Aubier, Collection Historique, París, 1988, p. 32. 
pensaron que Napoleón regresaría a Francia a través de España, lugar desde donde lideraba un ejército que luchaba contra la tiranía de los Borbones.

La imagen de Riego fue asociada a los referentes visuales del primero de los héroes románticos, el gran héroe corso. Rafael de Riego fue dibujado en la más conocida de sus representaciones con una mano metida dentro de su casaca, ${ }^{19}$ posición que rememoraba las representaciones del gran Emperador. La difusión de este gesto asociado al emperador fue tal que hasta en las capas más populares de la sociedad española, cuando se quería representar al Emperador francés, se usaba este gesto. Buena prueba de ello son las aleluyas sobre los disfraces de carnaval ${ }^{20}$ de la época, donde la imagen de Napoleón aparece vinculada a la postura anteriormente citada, y a la representación del Emperador montado a caballo alzando el brazo, popularizándose de esta forma la manera como fue pintado por David. Por todo ello, la representación de Riego hacía evidente el recuerdo de Napoleón, tanto entre los estratos más populares como en los más altos. La unión de Riego a la memoria del Emperador despertaba algunos temores entre la monarquía y los liberales más moderados, pero a la vez permitía recuperar algunos de los grandes principios revolucionarios que aglutinó a su alrededor el Emperador, consiguiendo atraer las miradas de Europa a la causa liberal española, internacionalizando el conflicto. Puede que fuera este uno de los motivos de que muchos liberales franceses vieran en la figura de Riego el hombre capaz mediante sus actos de devolver a Francia al camino del liberalismo. Aunque no debemos menospreciar la confusión que pudo generar entre los estratos populares franceses, la representación de Riego con todos los atributos visuales propios de Napoleón. Por lo tanto, deberíamos cuestionarnos si la asociación de ambos personajes fue voluntaria y si se intentó de esta forma, manipular y sublevar a las capas populares francesas alimentando el mito del regreso triunfal del Emperador.

Asistimos al nacimiento del gran mito romántico de Riego, divinizado como un nuevo Marte, como lo fuera en su día Napoleón. Así, la reinserción del Emperador en el liberalismo español ${ }^{21}$ fue legitimada por la admiración que despertaron sus acciones en el seno del ambiente romántico imperante. Pese ello no fueron pocas las voces disonantes con la figura del Emperador, así no deberíamos obviar la tergiversación que se pudo hacer desde las filas del moderantismo liberal y las del absolutismo de la

\footnotetext{
${ }^{19}$ Gil Novales, Alberto: Diccionario Biográfico del Trienio liberal (DBTL), El Museo Universal, Madrid, 1991.

${ }^{20}$ Galí Boadella, Montserrat: Imatges de la Memòria, el gravat popular a la Catalunya de la primera meitat del segle XIX, Editorial Altafulla, Barcelona, 1997-1999.

${ }^{21}$ Diario Constitucional, Político y Mercantil de Barcelona, 24 de febrero 1823: «Aunque traidor era un Marte: Tal fue un tiempo Bonaparte».
} 
vinculación de Riego con Napoleón, a partir de mediados del año 1822. ${ }^{22}$ Ambos sectores intentaron deslegitimar la figura de Riego convirtiéndola en la de un tirano, comparándolo a los tiranos populares surgidos de los procesos revolucionarios inglés y francés, es decir, Cromwell y Napoleón. La contextualización de los detalles de la imagen de Riego nos aportan algunos datos que diferencian la figura de éste respecto a Napoleón. El aspecto más sugerente de todos está presente en el monolito evocador de la Constitución de 1812. La disposición lumínica de la litografía ${ }^{23}$ (imagen 1) conduce al espectador a fijarse en ese detalle, resaltando así, la sumisión del héroe romántico a la voluntad de la nación española representada por los principios constitucionales de 1812, denostando cualquier deriva tiránica del régimen liberal. Otro elemento destacado de la litografía es la presencia al fondo de la imagen de un grupo de soldados reunidos en torno a una hoguera, rememorando al Ejército de la Isla, colectivo al cual siempre se relacionará con el liderazgo de Riego. Esta mención implicaba un posicionamiento político del autor de la imagen, pues la disolución del Ejército de la Isla se convirtió en caballo de batalla del enfrentamiento entre moderados y exaltados, puesto que la liquidación del Ejército significaba la finalización del proceso revolucionario sin haber conseguido satisfacer las reivindicaciones exaltadas. ${ }^{24}$ Desde las filas del liberalismo moderado, en los primeros años cuarenta del siglo XIX, se responsabilizó a Riego y a sus seguidores, los llamados «Rieguistas», de la desunión del liberalismo a causa de la vehemencia con que defendieron los postulados del liberalismo exaltado. ${ }^{25}$

Inicialmente, a Riego se le vinculó con otros tres héroes liberales, Quiroga, López Baños y Arco Agüero, siendo los cuatro cabecillas de los «Hêroes de la Isla», denominación que recibieron los miembros del Ejército de la Isla que había devuelto a España el régimen liberal. Al principio, durante 1820, Quiroga se convirtió en el individuo preeminente del cuarteto por ser el militar de mayor rango ${ }^{26}$ y por haber sido represaliado como consecuencia de su participación en la llamada «Conspiración del Palmar», aunque su acercamiento a los sectores moderados del liberalismo hizo que su imagen no llegara a las cotas de popularidad de Riego. Fue, sin embargo, López Baños el menos valorado de los héroes de la isla, pues su postración ante el primer gobierno moderado

${ }^{22}$ Gil Novales, Alberto: Rafael del Riego, La revolución de 1820, día a día, Editorial Tecnos, Madrid, 1975, p. 186: «Núm 233. Discurso de Riego defendiendo a Alcalá Galiano, en la Sociedad Landaburiana de Madrid (...) Nada me importa que aquí se haya dicho que Cromwell, Bonaparte y Itúrbide, se habían vuelto los tiranos de los pueblos. Riego siempre será Riego: Riego no se mudará y trabajará de continuo para asegurar la libertad de su patria. (El Indicador, núm. 245, 4 de enero de 1823, pp. 1029-1030)».

${ }^{23}$ Litografía de G. Engelmann, París, citado por Gil Novales, $D B T L$.

${ }^{24}$ Romeo Mateo, María Cruz: Entre el orden y la revolución..., p. 137.

${ }^{25}$ Sociedad Literaria: Historia de España desde los tiempos más remotos hasta el año 1840, Imprenta del Imparcial, Barcelona, 1845, p. 315.

${ }^{26}$ Gil Novales, Alberto: El Trienio Liberal, Editorial Siglo Veintiuno, Madrid, 1980, p. 3. 
del año 1820 frenó su popularidad y le hizo caer en el olvido. Ejemplo de ello fue la omisión o relegamiento de su figura a los confines del mundo simbólico liberal popular catalán, como lo demuestra su exclusión de la aleluya liberal de $1822,{ }^{27}$ donde su lugar en el cuarteto fue ocupado por Villacampa, elegido por aclamación popular como Capitán General de Cataluña en marzo de 1820 después de haberse proclamado la Constitución en Barcelona. Aunque no siempre éste fue el héroe escogido para sustituir a López Baños, pues en una de las hojas volantes ${ }^{28}$ distribuidas el año 1821 en Barcelona en su lugar encontramos a Milans del Bosch, uno de los organizadores del intento de rescatar en 1817 el general Lacy. En esta misma hoja volante, en una posición secundaria también aparecen los nombres de Villacampa y López Baños. Por consiguiente, podemos afirmar que el mundo popular liberal desestimó por su moderantismo al héroe López Baños y lo sustituyó, al menos en Cataluña, por otros héroes locales de mayor envergadura popular. El último de los miembros del cuarteto era Arco Agüero, el más próximo políticamente a Riego, pero sus acciones ambiguas y una muerte tan poco gloriosa como repentina en 1821 , fruto de una accidente de caza, le privaron de consagrarse como un mártir popular. A pesar de ello, los realistas en 1824 no se olvidaron de él y profanaron su tumba esparciendo sus restos. ${ }^{29}$ Más allá de los dos primeros años del régimen constitucional, la recuperación del cuarteto que protagonizó el pronunciamiento de 1820 se convirtió en una práctica recurrente para minimizar el efecto Riego entre las masas populares. Colocar en pie de igualdad a los «cuatro inmortales» implicaba descapitalizar la atracción popular de Riego, permitiendo reducir la incidencia de dicha personalidad en el seno del liberalismo popular y exaltado.

Una de la hojas volantes a la que anteriormente hacíamos mención, «La Letanía constitucional», nos permite introducir a otros héroes liberales de gran impacto en la cultura popular liberal de la ciudad condal. Casi todos estos héroes tenían algún tipo de vinculación con la figura de Lacy, entre ellos tenemos a Villacampa, a Milans del Bosch o a Díaz Morales, quienes participaron activamente en la conspiración de 1817 para derrocar el régimen absolutista o bien intentaron liberar a Lacy, antes de su ejecución. La misma Letanía también cita a Moreno Guerra quien conjuntamente al referido Díaz Morales han sido considerados por la historiografía como los introductores de la carbonería en España. Más allá de dicha letanía, nos hacemos eco de lo que escribe Gil Novales ${ }^{30}$ en su diccionario biográfico sobre la popularidad Moreno Guerra en Barcelona durante los años 1820 y 1821 .

${ }^{27}$ Vilanova, Josep: Auca de la Constitució, Secció de Gravats de la Biblioteca de Catalunya.

${ }^{28}$ Letania Constitucional, Barcelona: en la imprenta constitucional de Joaquin Jordi, calle de la librería, año 1821.

${ }^{29}$ Gil Novales, Alberto: DBTL.

${ }^{30}$ Ídem. 
La tesis de Ruiz Jiménez ${ }^{31}$ establece que todo el cuarteto del pronunciamiento de 1820 se integró en las filas de la comunería a partir del año 1821, aunque son evidentes su vinculación con las sociedades paramasónicas en el año $1820 .^{32}$ También Ruiz Jiménez cita como comuneros a Villacampa, Moreno Guerra y Díaz Morales. El único del grupo, citado en la letanía, que no consta que fuera comunero era Milans del Bosch, aunque su participación en el intento de liberación de Lacy le relaciona indefectiblemente con las sociedades paramasónicas. De esta manera, podemos llegar a la conclusión de que la comunión entre las distintas sociedades secretas era mayor de lo que a veces se ha dicho y que su participación en una de ellas no era excluyente de la vinculación a otras, dado que todas ellas compartían unos mismos referentes políticos y simbólicos.

A lo largo del año 1822 y 1823 creció la popularidad del general Espoz y Mina fruto de sus victorias contra los realistas. Pero entre las filas del radicalismo liberal barcelonés, el más vitoreado fue el Comandante de la Milicia Josep Costa, quien aglutinó al radicalismo liberal después de la epidemia de fiebre amarilla que asoló la ciudad durante el año 1821. Costa fue preso desde febrero a septiembre de 1822, y eso impidió su reconocimiento público, ya que su nombre se convirtió en un grito subversivo. Posiblemente, el culto a Costa se sublimó en virtud del culto a la Milicia Nacional Voluntaria.

Los colectivos más heroificados durante el Trienio por los sectores populares fueron el Ejército de la Isla y la Milicia. Esta última organización se erigió como uno de los pocos elementos de control sobre el gobierno. La Milicia encarnó al pueblo, al cual los exaltados atribuyeron el derecho a intervenir en los actos de gobierno, ya fuera a través de su movilización como acto de vigilancia revolucionaria, o mediante la supremacía del poder legislativo. El culto al pueblo en las filas del liberalismo iba mucho más allá del pueblo español, y en la propaganda liberal surgen referencias al pueblo francés, italiano y portugués, ${ }^{33}$ con la voluntad de internacionalizar la causa del liberalismo. Finalmente, hay un recuerdo para los héroes más cercanos y populares, esto es todos aquellos ciudadanos que participaron en el alzamiento del pueblo de Barcelona del 10

${ }^{31}$ Ruiz Jiménez, Marta: El liberalismo Comunero: Una consideración especial de el Zurriago (18211823), tesis doctoral dirigida por Alberto Gil Novales, Madrid, 1999. Inédita.

${ }^{32}$ Martín, Luis P.: «La Masonería y la conspiración liberal (1814-1834). Los límites de un mito histórico», Trienio, $\mathrm{n}^{\circ} 22$, noviembre de 1993, pp. 73-90.

${ }^{33}$ Letania Constitucional, Barcelona: en la imprenta constitucional de Joaquin Jordi, calle de la librería, año 1821; y Coplas Patrióticas. En honor de los soldados veteranos y milicianos locales, por la restauración de la Constitución de la Monarquía, Barcelona: En la imprenta Constitucional de Joaquin Jordi, calle de la Libretería: año 1821. 
de marzo de 1820, que facilitó la promulgación de la Constitución de 1812 en la ciudad, culto anónimo y local cercano al mito de «los vencedores de la Bastilla». ${ }^{34}$

\section{La construcción de un calendario liberal.}

La génesis del movimiento liberal español se constituyó en un debate visual para determinar cuál debía ser la fecha escogida. El historiador Butrón Prida, en su análisis de la fiesta constitucional en Cádiz, ya se hizo eco de la variedad de fechas fundacionales del liberalismo español. Butrón ${ }^{35}$ consideraba que la disputa para determinar la fecha iniciática del liberalismo se polarizaba en torno a dos fechas, por un lado, el 19 de marzo de 1812, día de la «Promulgación de la Constitución de 1812». Ese día era el que aunaba mayor consenso entre los distintos sectores del liberalismo. En Barcelona conservamos en la actualidad dos calendarios constitucionales ${ }^{36}$ referentes a los años 1822 y 1823 , donde aparece en la leyenda un número que hace referencia al «año de la Constitución» en que apareció el calendario, son los años once y doce de la Constitución respectivamente, fijando de esta forma el inicio del movimiento liberal en 1812. Por otro lado, la otra fecha usada fue el 2 de mayo de 1808, día del levantamiento del pueblo contra el opresor. La elección de este acontecimiento como jornada fundacional del liberalismo comportaba una lectura más moderada de los principios liberales, pues en esa fecha el pueblo no se insurreccionaba contra el tirano, sino contra el invasor francés. Por lo tanto, la toma de conciencia de la soberanía del pueblo se producía en un momento de vacío de poder, por la salida de España de la familia real. La institucionalización del pueblo en lucha contra el invasor permitía muchas lecturas diferentes, pero la consagración del hecho heroico del levantamiento popular desvirtuaba la obra liberal posterior, estableciendo el punto de partida no en la Constitución ni en la reunión de los representantes de la nación, sino en la respuesta del pueblo frente al invasor, un pueblo que con su acción pretendía manifestar su descontento y retornar a una situación anterior, así toda la obra constitucional posterior debería estar en función de la recuperación de los principios que habían regido España en otro tiempo. Esto posibilitaría una lectura más moderada de los principios liberales, ya que legitimaba una involución constitucional, pues el hecho fundamental era la resistencia del pueblo al invasor o al

${ }^{34}$ Vovelle, Michel: La mentalidad revolucionaria..., p. 136.

${ }^{35}$ Butrón Prida, Gonzalo: «Fiesta y Revolución...».

${ }^{36}$ Calendario del año 1822. Año Once De la Constitución Política. Para las provincias de Cataluña, Lérida, Tarragona y Gerona. Y Calendario del año 1823. Año Doce De la Constitución Polf́tica. Para las provincias de Barcelona, Lérida, Tarragona y Gerona. Dispuesto por el observatorio de Madrid según concesión exclusiva de las Cortes de 1820. Con el privilegio exclusivo de las Cortes. Barcelona: Por Miguel y Tomas Gaspar, bajada de la cárcel. Dispuesto por el observatorio de Madrid según concesión exclusiva de las Cortes de 1820. 
tirano y la voluntad de retornar a un régimen de libertades anterior, obviando cualquier tipo de principios y derechos políticos esenciales.

Esta dualidad no era tal, pues habría una tercera opción que consideraría que el desencadenante inicial del movimiento liberal se produjo el 24 de septiembre 1810 con la «Reunión de la Nación en Cortes Constituyentes». ${ }^{37}$ Esta era la elección más acorde con los principios liberales, ya que sancionaba la legitimidad de la Constitución de 1812 nacida de la idea liberal de soberanía nacional, ${ }^{38}$ pero limitaba la concepción divina de la Constitución, pues, en último término, la Constitución era obra de la soberanía de los hombres. La celebración de la reunión de la Nación en cortes constituyentes sancionaba la indivisibilidad de la soberanía nacional, alejando cualquier intento de reforma que no pasara por la voluntad del conjunto de la Nación, materializada en los representantes de ésta. La celebración de una fecha no implicaba la omisión de las otras, simplemente sucede que la primacía de una por encima de las otras comportaba una interpretación distinta de los límites liberales. Todas estas fechas fueron muy celebradas en Barcelona durante todos los años del Trienio, como ocurrió también con otras festividades, como fueron el 10 de marzo y el 31 de mayo. ${ }^{39}$ Sólo una excepción, el 24 de septiembre no se celebró en los años 1821 y 1822; en el primer caso probablemente se debiera a la epidemia de fiebre amarilla que asoló Barcelona en esas fechas, y al año siguiente es posible que la razón fuera el clima de tensión social extraordinario que vivía la ciudad después de los hechos acontecidos en la noche del 5 al 6 de septiembre de 1822 .

Hasta el momento, sólo nos hemos fijado en aquellas fechas consideradas como hitos fundacionales del liberalismo, sin embargo el calendario liberal era mucho más amplio. Durante los tres primeros meses del año se recordaba la proclamación de la Constitución de 1812, en el año 1820 en distintos lugares de la península. El día más destacado era el del juramento real de la Constitución, que se produjo el 9 de marzo de 1820, la propaganda visual del cual fue prácticamente nula, y simplemente existe un boceto de un dibujo, ${ }^{40}$ de esta manera, el monarca intentó no mostrarse ante sus súbditos jurando la Constitución para así poder facilitar una involución absolutista rápida. No fue hasta el 9 de julio de 1820 que encontramos las primeras imágenes del monarca jurando la Constitución en las cortes, una vez cerciorado de la imposibilidad de una regresión absolutista rápida.

${ }^{37}$ Vilanova, Josep: Auca de la Constitució, Secció de Gravats de la Biblioteca de Catalunya.

${ }^{38}$ Discurs pronunciat per lo R. P. prior de los carmelitas descalsos del poble de Gracia. Fr. Bonaventura de S. Lluis Gonzaga, en lo día de la colocació de Lápida constitucional en dit poble als 23 dezembre de 1821 , Barcelona: Per Miquel y Tomas Gaspar any 1822, p. 8.

${ }^{39}$ Yamamichi, Yoshiko: «Fiestas y celebraciones cívico-religiosas en la Barcelona Constitucional (18203)», I Congreso Virtual de Historia Contemporánea de España 2000. Revista (digital) Hispania Nova.

${ }^{40}$ Vega, Jesusa: Origen de la litografia en España. Real Establecimiento litográfico, Fábrica Nacional de Moneda y Timbre, Madrid, 1990, p. 70. 
La celebración del 10 de marzo era en honor a la proclamación de la Constitución en Barcelona y en recuerdo a las víctimas de Cádiz. A pesar de la institucionalización mediante un decreto de esa fecha como día de luto nacional, algunos calendarios liberales no la recogieron, como es el caso de los que hemos consultado. Puede que su omisión estuviera condicionada por el carácter popular de la conmemoración o, seguramente, por la desvirtuación que implicaba para la fiesta en honor al pueblo barcelonés, la coincidencia con los sucesos de Cádiz.

El calendario liberal también se hizo eco de todas aquellas jornadas gloriosas asociadas a hechos heroicos del pasado hispano. Entre ellas, encontramos la conmemoración de la derrota de Villalar, donde fueron vencidos los Comuneros en 1521, el día 23 de abril. Como también, la derrota el 3 de noviembre de los insurrectos Aragoneses de 1591, o el aniversario de los muertos en la guerra por el restablecimiento de la libertad en España, el día 31 de mayo. Anteriormente, ya hemos insistido en el culto liberal hacia las acciones insurreccionales del pueblo hispano contra la dinastía de los Austrias, y la negativa a celebrar las acciones de protesta contra la dinastía Borbónica, sin embargo, parece suficientemente revelador que dos de las principales acciones de protesta en Hispanoamérica, consideradas por la historiografía precedentes de la independencia, recogieran la tradición castellana, y se denominasen así mismos como "Comuneros», manteniendo vivas las acciones insurreccionales de los Comuneros castellanos del 1521. Primero, fueron los Comuneros de Paraguay en 1717-1735, y después, los Comuneros de Nueva España en 1781. A pesar de no haber encontrado ninguna referencia a ellos en el liberalismo español del Trienio, no podemos eludir la posibilidad del contagio político-simbólico entre liberales hispanos y rebeldes hispanoamericanos durante el primer exilio liberal. Las relaciones entre ambos lados del atlántico parecen más que evidentes cuando vemos que durante el Trienio también se conmemoró la figura de Mina, sublevado en Nueva España cuando intentaba instaurar un régimen liberal. Podría ser interesante observar si los liberales americanos releyeron su pasado más próximo en clave liberal, y si legitimaron con ese pasado las insurrecciones liberales para proclamar la independencia respecto a la metrópoli y si eso llegó a influir en los liberales de la metrópoli.

La imagen reafirma la primacía de determinadas fechas del calendario liberal. Los periódicos nos proporcionan una fuente iconográfica infravalorada muchas veces, no sólo nos pueden aportar imágenes que representan la realidad, sino que el formato del periódico habitualmente se convierte en sí mismo en una imagen. De este modo, a partir de la observación de dos periódicos liberales barceloneses obtenemos varias conclusiones. El primer diario, El Indicador Catalán, sólo varió su portada el año 1823 con 
ocasión de la celebración del 19 de marzo; ${ }^{41}$ la modificación sólo implicaba la inclusión en la cabecera del diario de una referencia al aniversario de la promulgación de la Constitución. El otro, El Diario Constitucional, Político y Mercantil de Barcelona, también durante el año 1823 , cambió su portada en tres ocasiones con motivo de la celebración del 19 de marzo, 23 de abril y 2 de mayo. ${ }^{42}$ Con ello, éste último codificaba de igual manera la importancia de las tres fechas para el liberalismo. Ello comportaba unas implicaciones simbólicas importantes y unas graves repercusiones doctrinales. De esta forma, mientras el Indicador Catalán dejaba claro cuál era su principal hito fundacional, el Diario Constitucional, Político y Mercantil de Barcelona, con la diversificación de fechas significativas, diluía los ejes liberales básicos en los que se fundamentaba, intentando que confluyeran en él distintos sectores del liberalismo.

La imagen en los periódicos no debe circunscribirse a los cambios de portada o de formato, habiendo que incluir las modificaciones en las imágenes de las cabeceras de los periódicos; un ejemplo lo encontramos en el Diario de la Ciudad de Barcelona, periódico liberal, donde de junio a octubre de 1822 aparecen en su cabecera dos figuras femeninas, una con la Constitución en la mano y la otra con las balanzas y la espada. ${ }^{43}$ La primera era una alegoría de la libertad o de la Constitución, mientras que la segunda nos remitía a la idea de justicia. Estas imágenes nos muestran la fuerza que la tradición grecolatina tuvo en la Revolución Liberal.

\section{Los referentes clásicos interpretados a la luz idealizadora de la revolución. ${ }^{44}$}

Los mitos clásicos y la historia antigua, como había sucedido en Francia durante la Revolución, fueron reinterpretados a la luz de los acontecimientos revolucionarios, siendo habitual denominar a los héroes como Espoz y Mina o Lacy como Marte, dios de la guerra, o designar el campo de batalla como Campo de Marte.$^{45}$ Más allá de los héroes que se batieron contra el despotismo, también se ensalzó la obra de los representantes de la Nación reunidos en las Cortes Constitucionales, como Padres de la Patria o en la designación clásica usada como Solones y Licurgos. ${ }^{46}$ El primero, Solón, elaboró

${ }^{41}$ Indicador Catalán, no 78, 19 de marzo de 1823, p. 1.

${ }^{42}$ Diario Constitucional, Político y Mercantil de Barcelona «Constitución o Muerte», $\mathrm{n}^{\circ} 78,19$ de marzo de 1823, p. 1. Diario Constitucional, Político y Mercantil de Barcelona «Constitución o Muerte», $\mathrm{n}^{\circ} 113,23$ de abril de 1823, p. 1. Diario Constitucional, Político y Mercantil de Barcelona «Constitución o Muerte», $\mathrm{n}^{\circ}$ 122, 2 de mayo 1823 , p. 1.

${ }^{43}$ Diario de la Ciudad de Barcelona durante el año 1822.

${ }^{44}$ Butrón Prida, Gonzalo: «Fiesta y Revolución...».

${ }^{45} \mathrm{La}$ Voz del Pueblo, $\mathrm{n}^{\circ}$ 12, 9 de junio de 1822: «Si hasta ahora sólo hemos sido buenos para un servicio pasivo y para las paradas, ya es de menester que entremos en servicio activo, tomemos todos el fusil y corramos al Campo de Marte a acabar con nuestros enemigos o hacer que ellos acaben con nosotros».

${ }^{46}$ Discurs pronunciat per lo R. P. prior de los carmelitas, p. 16. 
como reformador y legislador la nueva Constitución que ponía fin a las grandes diferencias económico-sociales existentes entre los habitantes de Ática. Se glorió de no haberse constituido en tirano a pesar de su enorme popularidad. La antigüedad veneró su recuerdo e incluyó su nombre en las listas de los siete legendarios sabios de Grecia. Su nombre siempre estuvo muy ligado a la tradición democrática ateniense. El segundo, Licurgo, es el nombre de un personaje legendario al cual la tradición clásica atribuye la Constitución de las leyes y de las costumbres de los lacedemonios, que lo consideraron un ser prácticamente divino, en sí mismo una representación de la libertad. Por otro lado encontramos varias maneras de denominar el espacio donde había Cortes, al espacio ocupado en Cádiz se le llamó el Templo de Minerva ${ }^{47}$ diosa de la guerra y tutora de la libertad ciudadana, mientras que al ocupado en Madrid recibió el nombre de Templo de la Razón. ${ }^{48}$

La tradición grecolatina sirvió para inspirar la construcción de monumentos, entre ellos los más destacados en Barcelona fueron el Templo de la Libertad Civil construido para celebrar las exequias del General Lacy, en julio de 1820. Este templo tenía una forma circular y cada una de sus ocho columnas hacían referencia a alguno de los mártires muertos en defensa de la libertad española, los héroes incluidos iban desde los comuneros hasta los muertos en el pronunciamiento de $1820 .{ }^{49}$ El templo se ubicó en el interior de la iglesia de Santa María del Mar de Barcelona. La estructura circular del templo y su dedicación a los mártires de la libertad denotan una más que probable influencia francesa, ya que en la Montaña construida en el Campo de Marte en París, había un templo circular dedicado a los mártires de la patria. ${ }^{50}$ Otro Templo construido en Barcelona estuvo dedicado a la Diosa Libertad, ${ }^{51}$ el artífice de la obra fue Antonio Genesi (vice-cónsul de la Toscana en Barcelona) con motivo de la celebración del tercer aniversario de la proclamación de la Constitución en Barcelona y del cuarto aniversario de la promulgación de la Constitución de 1812. El templo estaba ubicado en el centro de la plaza de la Constitución e, igual que el anterior, era una construcción destinada a

${ }^{47}$ Discurs pronunciat per lo R. P. prior de los carmelitas, p. 21.

${ }^{48}$ Edicto del Gobernador Superior de Cataluña a todos los alcaldes (...) 18 de septiembre de 1821.

${ }^{49}$ Relación de la pompa fúnebre con que en el mes de julio de 1820 y en virtud de real aprobación se celebraron en esta capital las triunfales exequias al cadáver del excelentísimo Sr. D. Luis Lacy capitán general de los ejércitos nacionales arcabuceado en el castillo de Bellver en la isla de Mallorca el 5 de julio de 1817, víctima del despotismo, que en aquella época afligía a la nación española. Redactada por disposición de la junta patriótica en honor del esclarecido ciudadano Lacy, Barcelona, imprenta de Juan Dorca.

${ }^{\text {so }}$ Vovelle, Michel: La mentalidad revolucionaria..., p. 180.

${ }^{51}$ Diario Constitucional, Polftico y Mercantil de Barcelona "Constitución o Muerte», $\mathrm{n}^{\circ} 80,21$ de marzo de 1823: «Presentarse un espectáculo más digno de la festividad del día, que el que este año ha dispuesto el ayuntamiento, y tuvo lugar en la plaza de la Constitución. Tal fue en efecto la coronación de los cinco predilectos hijos de la patria, heridos en el campo del honor, efectuado en el templo de la libertad, entre el estrepitoso ruido del cañón, los alegres ecos de las músicas militares, y las ardientes aclamaciones del inmenso pueblo espectador". 
ejercer una función pedagógico-simbólica en la conciencia política de los ciudadanos. Estas eran construcciones con una temporalidad muy marcada y donde la funcionalidad era determinada por su significado, el cual debía ser lo más comprensible posible para el conjunto de los ciudadanos. La historiografía francesa vio en la recuperación de la simplicidad de las formas clásicas, una opción que va más allá de un sencillo cambio estético, y la interpretan como la voluntad del hombre de volver al estado de naturaleza, ${ }^{52}$ aunque para el caso hispano creemos que es una afirmación demasiado arriesgada, y debería matizarse.

Desde algunos círculos de radicalismo liberal se afirmaba que los liberales españoles eran «idólatras de la libertad y de la Constitución como en su día lo habían sido los jacobinos franceses». ${ }^{53}$ Buen ejemplo de ello, lo descubrimos en el análisis de la matrona liberal con un ejemplar de la Constitución de 1812 en una de sus manos. Esta matrona fue interpretada de varias maneras distintas, unos vieron en ella la alegoría de la Constitución, otros a la Diosa de la Libertad. La difusión de la imagen de esta mujer vestida a la manera clásica sujetando la Constitución en su mano fue enorme durante el Trienio. La encontramos en grabados más o menos populares, ${ }^{54}$ descripciones de estatuas aparecidas en periódicos, etc.

La interpretación iconográfica fue, sin duda, polémica, como lo demuestra la falta de consenso existente alrededor del significado de la matrona. Para unos, esta figura era una alegoría de la Constitución, identificación que se fundamentaba en dos argumentos, por un lado la mayoría de los insignes liberales retratados en los cuadros pintados durante el Trienio ${ }^{55}$ aparecen sujetando el «libro de la Constitución» y por el otro, muchos de los impresores intentaron esclarecer cualquier posible duda con una inscripción aclaratoria referida a la Constitución. Para otros, y sobre todo cuando no había letras que leer o no se sabían leer, esa matrona era percibida como la diosa de la Libertad, ${ }^{56}$ haciéndose eco de la iconografía de la Revolución Francesa. No es menos cierto

52 Starobinski, Jean: 1789. Los emblemas de la razón, Taurus, Madrid, 1988, p. 42.

${ }^{53}$ Indicador Catalan, $\mathrm{n}^{\circ} 234,1$ de octubre de 1822, p. 3: « En Barcelona se proclamó el 5, no la República, bribones sino vuestra sentencia de muerte, y la de combustión de vuestros inmundos cadáveres, que tarde o temprano tendrán la misma muerte que vuestros papeluchos (...) no ya algunas docenas de Jacobinos, sino 12 millones de españoles peninsulares, igualmente idolatras de su libertad y Constitución».

${ }^{54}$ Instrucció breu de la Constitució, y de lo mes principal que se conté en ella. Ho dedicá á la Patria lo ciutadá I. P. J. Barcelona: En la estampa de Silveri Lleyxá á la Daguería, any 1820 (grabado).

${ }^{55}$ Tuero Bertrand, Francisco: Riego proceso a un liberal, Ediciones Nobel, Oviedo, 1995. Retrato del Coronel R. Riego que aparece en la p. 13. O los retratos de los obispos, Pedro González Vallejo (obispo de Palma de Mallorca) y de Antonio Posada Rubín de Celis (obispo de Cartagena) que aparecen en el libro de Manuel Revuelta Política religiosa de los liberales en el siglo XIX. El Trienio Constitucional, Madrid, CSIC, 1973.

${ }^{56}$ Diario Constitucionah Politico y Mercantil de Barcelona «Constitución o Muerte», $\mathrm{n}^{\circ} 80,21$ de marzo de 1823: «Un magestuoso templo se elevaba como hemos dicho en medio de la plaza: sus adornos eran los emblemas del código fundamental, y de las glorias adquiridas por el ejército permanente y milicia nacional en 
que en el año 1823, al menos en Barcelona, existía un consenso alrededor de la iconografía de la diosa de la Libertad, pero lo sorprendente fue que para encarnar la figura de la divinidad se usaran los mismos rasgos iconográficos que habían permitido caracterizar la alegoría de la Constitución. Esto implicaba la confusión de ambas figuras y la voluntad de integrar ambos significados en una misma representación iconográfica. Con todo, quedaba patente la existencia de un culto a la libertad previo a 1823, pero que las circunstancias municipales y estatales no habían permitido desarrollar a un nivel institucional. Por lo tanto, los idólatras de la libertad habían usado la profusión de imágenes alegóricas de la Constitución para encuadrar la divinización de la libertad, produciéndose, de esta manera, interpretaciones distintas de una misma representación iconográfica en función de los ojos que la miraran. No fue hasta 1823, en una Barcelona en manos de los exaltados y amenazada por los franceses, cuando se intentó que confluyeran dichos cultos en uno, y así aglutinar cualquier posible desunión en el seno del liberalismo. ${ }^{57}$ Empezaba entonces a manifestarse sin tapujos el culto a la Diosa Libertad. No obstante, la matrona española difiere de la diosa de la Libertad francesa en algunos detalles, pero como afirma Burke ${ }^{58}$ cada imagen tiene que ser analizada en función de su contexto y de cómo fue analizada por sus contemporáneos. Por lo tanto, la inclusión de inscripciones iría dirigida a cerrar en un único significado la lectura de la imagen, rehuyendo cualquier interpretación distinta. Recuperando una idea de Burke, ${ }^{59}$ todas las interpretaciones serían correctas porque nos ayudarían a explicar como percibían las imágenes el conjunto de la población.

La tradición clásica fue utilizada para corporificar la Nación, mientras los franceses habían usado la figura de una mujer para simbolizar a la Nación, los liberales españoles prefirieron remitirse a una figura masculina vestida a la manera clásica, seguramente, porque la mujer representación de la Nación francesa estaba demasiado vinculada a la concepción de República, de la cual querían desligarse los liberales españoles.

la dolorosa lucha contra el fanatismo: vistosos grupos de armas colocadas a proporcionadas distancias: las escaleras, sembradas de flores: las cuatro provincias, y cuatro virtudes cívicas que representaban figuras alegóricas: la diosa de la libertad con la Constitución en la mano (...) de esa Constitución, ídola del pueblo español (...) era el Númen tutelar del templo. La rodeaban las músicas militares, y le hacían la guardia ocho centinelas a la vez, colocados en los descansos de las escaleras».

${ }^{57}$ Indicador Catalán, $\mathrm{n}^{\circ}$ 80, 21 de marzo de 1823, p. 3: « ¡Barcelona.! ¡Tu eres la primera ciudad de la monarquía en que se elevara un templo de la libertad. Un templo que no, no contraría los derechos de la divinidad, si que acata por el contrario el primer don y es el hijo primogénito de aquella!»

${ }^{58}$ Burke, Peter: Visto y no visto, el uso de la imagen como documento histórico, Editorial Crítica letras de la humanidad, Barcelona, 2001, p. 81.

${ }^{59}$ Ídem, p. 231. 


\section{Vestirse para la política durante el régimen liberal del Trienio.}

El historiador Fuentes Aragonés ${ }^{60}$ ya demostró la originalidad del vocabulario político liberal español. La influencia del vocabulario de la Revolución Francesa era destacable pero no determinante. El liberalismo español tradujo algunos términos franceses, como Sans-culottes, que primero fue traducido por «sin calzones» aunque la acepción que tuvo más adeptos fue la de «descamisado». Los periódicos liberales a partir de la catalogación de los liberales más exaltados como descamisados establecieron toda una inmensa gradación de niveles en el mundo liberal a partir del uso de las camisas, ${ }^{61}$ dando lugar a expresiones como «lleva muchísimas camisas» 0 «no lleva ni una hilacha de camisa».

Una de las otras prendas distintivas del liberalismo fueron los «gorros». Fuentes Aragonés en su estudio apuntaba la posibilidad de un préstamo simbólico a partir del «bonnet rouge» francés. Pero debemos tener en cuenta otros aspectos; el primero de ellos es la posibilidad de que ese gorro tuviera una existencia física que fuera más allá de su existencia simbólica, y esto no supondría una desestimación de la hipótesis del contagio simbólico francés. En el año 1824, los represores absolutistas prohibieron el uso del gorro denominado popularmente cachucha por su carácter subversivo, equiparando su potencial revolucionario, a los gritos a favor de la Constitución y de Riego. ${ }^{62}$ En segundo lugar, si el gorro se materializa físicamente, quiénes los llevan y qué comportaba llevarlo. En uno de los pocos dibujos que tenemos de Romero Alpuente ${ }^{63}$ nos los presentan con un gorro, pudiera ser este el gorro llamado cachucha. El significado del gorro parece claro, ya que se refiere al radicalismo liberal más popular, tal y como lo demuestran las referencias en las Actas del Ayuntamiento de la ciudad de Barcelona y distintos artículos aparecidos en el Diario de la Ciudad de Barcelona ${ }^{64}$ o La Voz del Pueblo. ${ }^{65}$ Como había sucedido con el término «descamisado» también

${ }^{60}$ Fuentes, J. F.: «Aproximación al vocabulario socio-político del primer liberalismo español...», p. 62.

${ }^{61}$ La Voz del Pueblo, $n^{\circ} 12,9$ de junio de 1822: «Semblanzas (...) Generes. ¿Que talentos los que nos 3 alcaldes abogados? (...) Es hombre grueso, y lo parece más de lo que es realmente porque lleva muchas camisas (...) Bruno Petrus. Lleva muchas camisas, que no se le ponen mugrientas a pesar de que podria set (...) Es y ha sido amigo de las damas; lo es del orden; pero no de las tribunas, que en el día estan cerradas en Barcelona».

${ }^{62}$ Sociedad Literaria: Historia de España desde los tiempos más remotos hasta el año 1840, Imprenta del Imparcial, Barcelona, 1845, p. 370.

${ }^{63}$ Vega, Jesusa: Origen de la litografia en España. Real Establecimiento litográfico..., p. 71.

${ }^{64}$ Diario de la Ciudad de Barcelona, $n^{\circ}$ 186, 8 de diciembre de 1822, p. 499; «Gacetín (...) Anilleros: los de esta ciudad decían ayer en cierto parage que estaban muy mal, por haber recaído el nombramiento de electores en los descamisados, y que por lo mismo el año proximo tendríamos un ayuntamiento gorro!»

${ }^{65}$ Voz del Pueblo, $n^{\circ} 26,27$ de agosto de 1822: «Semblanzas (...) Ramón Maria Sala Comandante del $2^{\circ}$ Batallon de la Mílicia de Reglamento (...) De estos antecedentes deducimos, nos los semblancistas; por una consecuencia precisa que Sala es patriota; y hechos públicos sus méritos y el defensor de Costa: o arree con nosotros su batallon contra los enemigos de nuestras instituciones, o aunque gorro, sin gorro mire viscamente 
nacerán otros vocablos por contraposición a «gorro», el periódico el Indicador Catalán ${ }^{66}$ citaba a los «desgorrados». Finalmente, ¿quiénes lo llevaban? Seguramente, su uso era habitual entre las clases populares hispanas, con distintas variaciones en función de las zonas de la península. Su génesis como elemento político debemos buscarlo en una mezcla entre la tradición popular hispana y el contagio simbólico francés, puede que de esa forma pudiéramos asimilar el término cachucha al de la barretina catalana. Años más tarde, en 1842, percibimos una continuidad en el uso del gorro como atributo político, como nos ha mostrado Elorza, ejemplificándolo a partir del periódico barcelonés El Republicano, en la primera página del cual aparecía el hombre del pueblo, un sans-culotte catalán, armado con una pica y tocado de una barretina / gorro frigio. ${ }^{67}$ Volviendo de nuevo al Trienio, conviene especificar que hay algunas variaciones del término «gorro» a las cuales les acompaña un adjetivo, como es el caso de los «gorros morados», que sin duda hacían referencia al colectivo comunero radical, pues el morado era el color propio de la comunería.

El uso de brazaletes fue habitual desde el inicio del Trienio, en éstos se podían leer lemas como «Constitución o Muerte» o «Libertad Constitucional»; el color era amarillo o verde, este último asociado a la masonería. Las autoridades llevaban masivamente estos distintivos en días de celebración del liberalismo, las llamadas fiestas cívicas. Con todo, la extensión de esta práctica entre el conjunto de la ciudadanía no estuvo libre de problemas, pues en el Diario de la Ciudad de Barcelona leemos un artículo donde siete milicianos se quejan de haber sido detenidos por llevar un brazalete verde con la inscripción «Libertad Constitucional» y no habérselo querido quitar. ${ }^{68}$ Por consiguiente, su uso iba más allá de una simple publicidad de sus ideas ya que comportaba tomar parte en una opción política exaltada de manera pública, que frecuentemente podía degenerar en una insurrección. Estos eran los peligros que intentaban ahuyentar las

o la Ciudadela o el Lavadero público».

${ }^{66}$ Indicador Catalán, $\pi^{\circ}$ 60, 15 de marzo de 1822, p. 238: «El Excmo. Sr. Jefe político dio las gracias a la guarnición y milicia de esta ciudad por lo bien q se condujeron en la ocurrencia del 24 último de febrero. (...) Quisiéramos, pues, que todo individuo de este pueblo, que tenga camisa o descamisado, que cale gorro o desgorrado, liberal o servilón, anarquista o pancista, republicano o de dos cámaras, francmasón o de la Santa hermandad, exaltado o pastelero, moderado o cero, que los editores del Espectador y del Independiente, los del Censor, Imparcial o Constitucional, se manifestasen agradecidos».

${ }^{67}$ Elorza, Antonio: «El tema de Francia en el primer republicanismo español», en Aymes, Jean-René y Fernández Sebastián, Javier, La imagen de Francia en España (1808-1850), Servicio Editorial Universidad del País Vasco, 1995, p. 114.

${ }^{68}$ Diario de la Ciudad de Barcelona, $\mathrm{n}^{\circ}$ 129, 6 de septiembre de 1822, p. 3: «Caso raro. Siete individuos acérrimos defensores de las libertades patrias, que pertenecen a la artillería nacional voluntaria fueron arrestados de orden del capitán de la misma arma Erasmo Janer y de Gónima por no haberse querido quitar la cinta verde de Constitución o muerte. Pregunto ¿si hubieran llevado anillo se habría dado aquella anticonstitucional orden?= Uno de los arrestados». 
autoridades al restringir el uso de los brazaletes sólo a los días señalados como festividades cívicas, y reprimir aquellos individuos que no obedecieran las órdenes.

\section{La religión católica frente al culto de la libertad.}

Alrededor de la representación simbólica de la religión católica se obtuvo el consenso en torno a una figura femenina cubierta por un manto y que sujetaba en una de sus manos la cruz. Esta representación simbólica se difundió entre la cultura de elite y por contagio llegó a la cultura popular. Los ejemplos perceptibles de comunión entre las dos culturas los observamos en la aleluya de 1822 y en el templo conmemorativo a Lacy de 1820.

No cabe duda que no siempre la recepción del lenguaje visual fue tan buena. Prueba de ello son las críticas que despertó en unos de los periódicos católicos de Barcelona, El Verdadero Amigo de la Religión, ferviente defensor del liberalismo, la incorporación del lenguaje liberal a las imágenes religiosas. ${ }^{69}$ Algunas hojas volantes, como las «Décimas constitucionales al divino redentor», donde se mezclaban temas e imágenes religiosas con motivos políticos liberales, esta propaganda solía introducirse entre las hojas de los libros que había en la iglesia para los feligreses. ${ }^{70}$ Pero la fusión de las imágenes del credo católico con el nuevo régimen liberal no gustó ni tan siquiera a aquellos eclesiásticos que eran fervientes defensores del nuevo sistema político.

El uso de fórmulas como la letanía para alabar a los héroes no era una novedad del liberalismo español, pues en la Francia revolucionaria el culto del héroe más popular, Marat, se difundió mediante las «Letanías del Sagrado Corazón de Marat». ${ }^{71}$ Anteriormente, en el análisis al mundo de los héroes ya hemos mencionado todos los héroes españoles que aparecían en la Letanía Constitucional.

Simbólicamente, el atentado más duro contra la religión católica fue la divinización de la Constitución de 1812. En general, la Constitución se presentaba como una fuente de luz que era la encargada de disipar las tinieblas del despotismo, rememorando el mito solar $^{72}$ de la Revolución mediante la metáfora de la luz vencedora frente a las tinieblas. Pero cuando esta luz constitucional se insertaba en un triangulo símbolo de la divinidad, esto irrefutablemente evocaba la tradición deísta masónica que confluía en el liberalismo y que atemorizaba a los católicos más obstinados.

69 Dufour, Gérard: «Una efimera revista religiosa durante el Trienio liberal El verdadero amigo de la religión», Trienio, $\mathrm{n}^{\circ}$ 9, mayo 1987, p. 171.

70 Soberanas, Amadeu, J.: «Aribau i el guiatge de Fèlix Torres Amat», pp. 27-40. A.A.D.D: Commemoració de la Renaixença, Editorial Fundació Jaume I, Barcelona, 1982.

${ }^{71}$ Vovelle, Michel: La mentalidad revolucionaria..., p. 138.

${ }^{72}$ Starobinski, Jean: 1789. Los emblemas de la razón, Taurus, Madrid, 1988, pp. 27-32. 
La extensión de la devoción a la lápida constitucional estaba asociada al culto a la Constitución de 1812. Sin embargo, la veneración de la lápida no fue la única forma que adoptó el culto constitucional y la historiografía ha obviado otras prácticas simbólicas ligadas a ese culto. En una ciudad como Barcelona fue habitual que hubiera iniciativas para cubrir toda la fachada de la catedral con los artículos de la Constitución, y aunque, nunca se llevó a cabo, se pintaron artículos de la Constitución en las fachadas de las iglesias parroquiales y en los claustros de los conventos. La profanación del espacio católico sagrado se hizo con el fin de fomentar la publicidad de la Constitución de 1812, intentando que el conjunto de la sociedad no sólo leyera los artículos, sino que los analfabetos simplemente los vieran en los lugares de culto. Sin duda, ver las fachadas e interiores de los edificios eclesiásticos cubiertos por artículos de la Constitución no gustó a todo el mundo, disgustó especialmente al mundo eclesiástico, siendo habitual que dichos artículos amanecieran saboteados mediante graffitis. ${ }^{73}$ El catolicismo más intransigente interpretó los artículos constitucionales como un acto de profanación, de anticlericalismo y algunos hasta de iconoclasia. Pero, si algunas prácticas merecen el calificativo de iconoclastas, éstas fueron las que sabotearon los artículos pintados en las fachadas y paredes de los edificios de las ciudades.

\section{La iconoclasia de las imágenes del liberalismo.}

Fueron muchas las imágenes que desaparecieron con el fin del Trienio, eso nos puede permitir comprender por qué han llegado hasta nuestros días tan pocas. De esta manera, hay que considerar que la producción iconográfica liberal durante el Trienio fue más importante de lo que las imágenes supervivientes muestran. Para hacer una historia del mundo visual liberal hemos de tener presente todas aquellas imágenes que por un motivo u otro no hemos preservado, pero que tenemos constancia de su existencia. A continuación, mencionaremos algunas de las obras que sufrieron la furia iconoclasta de la represión absolutista a partir de 1823. Naturalmente, si la represión fue durísima entre distintos sectores sociales y políticos, aún fue más virulenta contra los objetos, y asimismo se produjeron numerosísimos actos iconoclastas.

La destrucción de las lápidas constitucionales fue la manifestación iconoclasta más reseñada por la historiografía, no obstante estos actos no fueron los únicos. La historia del arte nos aporta detalles de tres ejemplos de destrucción de imágenes significativas del liberalismo: -La desaparición de un cuadro de Salvador Mayol, la descripción del cual nos informa de la presencia de una alegoría de España recuperando sus derechos a través de la Constitución y ahuyentando los monstruos del error y de la esclavitud. - La

${ }^{73}$ Curet, Francesc: Rebomboris i bullangues de Barcelona, Vol. II, Ed. Bruguera, Barcelona, 1971, p. 152. 
destrucción de una miniatura de la esposa de Riego, firmada por Goya. ${ }^{74}-Y$ por último una litografía de Arco Agüero, de la cual los periódicos dejaron constancia, pero que, como sucediera con su tumba y cadáver, fue objeto de la brutalidad represora absolutista. $^{75}$

Este es un campo de investigación todavía sin explorar y más aún cuando no nos ceñimos a obras de una excelsa calidad, sino que intentamos reseguir la imagen como fuente de información y no en función de su calidad artística. Sin ir más lejos, la obra reciente de Ramon Arnabat ${ }^{76}$ nos informa de varias estatuas en honor a la Constitución levantadas en ciudades catalanas como Vic o Figueres, de las cuales no tenemos ni restos ni dibujos que nos mencionen cómo eran.

\section{Conclusión: la imagen generadora y difusora del discurso político liberal.}

Tres muestras iconográficas nos ayudarán a ejemplificar cómo la imagen produce un discurso político a partir de la elección de determinados elementos simbólicos. En cada una de las siguientes imágenes observamos cómo los diferentes sectores del mundo liberal conciben los principios que deben regir a la sociedad naciente. Uno de los principales problemas con el que nos enfrentamos es la dificultad para documentar el modo como fueron percibidas las imágenes por el conjunto de la población. Ineluctablemente la recepción de la imagen determinó su pervivencia, ayudando a codificar una serie de contenidos que no siempre podían expresarse libremente a través de la palabra. Las imágenes impactaron en las conciencias de la ciudadanía visualizando algunos de los principios que debían regir la nueva sociedad. Mientras fueron muchos los que intentaron conducir el significado de las imágenes con la palabra escrita, su éxito fue relativo, pues la iconografía liberal rápidamente fue apropiada por el pueblo, dándole vida propia. El discurso político buscó en las imágenes el instrumento ideal para penetrar en sectores populares, hasta el momento poco politizados. Pero se olvidaron de la capacidad del pueblo para generar un discurso político en los márgenes ideológicos del sistema político. A continuación, nos ocupamos de analizar cómo la imagen ayudó a fijar los principios esenciales del liberalismo exaltado, radical y moderado.

- La primera de ellas (imagen 2) hace referencia al asalto al Palacio de la Inquisición de Barcelona el 10 de marzo de 1820, el mismo día de la proclamación de la Constitución en la ciudad condal. Esta imagen es una litografía francesa de Engelmann a partir de un dibujo de Lecomte de 1820 y lleva el título de la «Destrucción de la

\footnotetext{
${ }^{74}$ Baticle, Jeannine: Goya, Editorial Crítica, Serie Mayor, Barcelona, 1995, p. 301.

${ }^{75}$ Vega, Jesusa: Origen de la litografía en España. Real Establecimiento litográfico..., p. 71.

${ }^{76}$ Arnabat Mata, Ramon: La revolució de 1820..., p. 33.
} 
Inquisición de Barcelona». ${ }^{77}$ El espectador cuando observa la litografía fácilmente rememora la acción de la toma de la Bastilla de 1789. La imagen del asalto a la Bastilla marcó un hito en la iconografía de la época, dado que reproducía por primera vez de manera enaltecedora un acto tumultuario de carácter popular. En esta misma línea, el asalto del Palacio de la Inquisición apuesta por la celebración de la acción multitudinaria protagonizada por el pueblo, rindiendo pleitesía a la idea de la insurrección popular contra la opresión y el fanatismo pero sin que en ningún momento se nos formule dicha acción de forma violenta. El elemento que nos hace más evidente la voluntad de plasmar la serenidad popular en el dibujo es el trato dado a los clérigos. Ellos se alejan de palacio, no son represaliados, no huyen pero, a pesar de ello, su ubicación en el espacio central de la imagen le confiere un carácter marcadamente anticlerical, como queda ratificado con la representación demoníaca de los inquisidores, quienes cubiertos con sus atuendos negros no nos dejan ver sus caras. Alrededor del grupo observamos tres personajes mirando a los eclesiásticos, uno de los manifestantes insta al grupo a girarse y observar cómo es destruida la sede inquisitorial. Frente a los eclesiásticos un niño temeroso se aferra a su madre, ella intenta disipar sus miedos acercando su mano hacia los inquisidores. La mujer con su gesto abre la puerta a los eclesiásticos para integrarse en el nuevo régimen constitucional naciente, un nuevo sistema político donde no se pretende excluir a nadie, donde se persigue el fanatismo pero no el catolicismo ni sus ministros.

La Inquisición para el liberalismo fue la encarnación máxima de fanatismo, de represión y de coerción de las libertades individuales y por lo tanto, no tiene espacio en el nuevo orden reinante. El asalto a los tribunales de la Inquisición no fue una práctica circunscrita a la ciudad de Barcelona, sino que se produjo también en otras ciudades, como Madrid o Valencia. ${ }^{78}$ El ataque a los edificios de la Inquisición en estas tres ciudades se produjo en todas ellas pocas horas después de la proclamación de la Constitución en la ciudad. El fin de la opresión es atestiguado por las cadenas rotas que aparecen por doquier en la imagen pero también por la quema de procesos inquisitoriales, elementos ambos que nos evocan la simbología de la libertad asociada al liberalismo. Asimismo la presencia de rejas en las ventanas enfatizan la sensación de represión que percibe el espectador.

La acción tumultuaria es instituida como práctica revolucionaria liberal mediante una serie de rasgos como son la eliminación de todas las características peyorativas que para la mayoría de contemporáneos comportaba un hecho revolucionario, de este modo

7 Sobrequés i Callicó, Jaume (dir.): Història de Barcelona, Vol. 5. El desplagament de la ciutat manufacturera (1714-1833), Editorial Enciclopèdia Catalana, Barcelona, 1993, pp. 312-3.

${ }^{78}$ Romeo Mateo, María Cruz: Entre el orden y la revolución..., p. 89. 
la violencia desaparece de los ojos del espectador, y se minimiza la participación de las mujeres en lo sucedido, sólo apareciendo como simples espectadoras del asalto. Otra característica visual de la práctica revolucionaria liberal la percibimos en el ósculo de la fraternidad entre dos liberales, el cual es una reminiscencia de un acto frecuente en la Francia revolucionaria, y nos acerca visualmente a dos procesos característicos del liberalismo español de los años veinte, por un lado la necesidad de unidad de los liberales frente al despotismo, y por el otro, la internacionalización de la causa liberal española en toda Europa. ${ }^{79}$ En el centro de la imagen, dos individuos ignoran el grupo eclesial, dando la espalda al espectador mientras contemplan la acción de sus conciudadanos. Su actitud y ubicación les acerca al espectador, al observar el espectáculo revolucionario. La observación detallada de cada uno de ellos nos percata de las diferencias existentes; uno lleva todos los atuendos propios de las clases populares, el otro, por el contrario, viste con las ropas propias de la clase dominante. Ambos nos sugieren la comunión de los dos grupos en la acción. La confluencia de dichos grupos queda corroborada con la observación de la multitud asaltante. Antes ya hemos hecho hincapié en la nula presencia de las mujeres en el asalto al tribunal, pero habría un detalle más significativo como era la desaparición de las mujeres de los estratos populares de la imagen, confiriendo existencia sólo a la mujer burguesa, adoptando ésta una actitud de gregaria en la acción y encomendando sus atenciones al auxilio de los débiles, ya sean éstos niños o enfermos. Estamos, de hecho, en la génesis de la moral burguesa, al tiempo que la imagen pretende fijar un modelo femenino silenciando u omitiendo cualquier presencia femenina en la acción política.

Finalmente, podemos ver dos miembros del ejército montados a caballo en cada uno de los lados de la imagen, celebrando la acción del pueblo, reforzando así la idea de un ejército comprometido con el régimen constitucional y dinamizador del proceso revolucionario, aunque sin llegar a tener un papel protagonista. Esta imagen nos ilustra la manera como percibieron los liberales europeos, incluso los españoles, la Revolución de 1820 , también nos acerca a la génesis de los temas esenciales del moderantismo liberal, esto es la unidad, la seguridad enfatizada con la no violencia, el control de las masas populares, entre otros aspectos ya mencionados.

- La siguiente imagen (imagen 3) está inserta en uno de los formatos típicamente populares del Antiguo Régimen, confiriéndole un carácter marcadamente popular: es la Aleluya sobre la Constitución publicada en 1822 por el impresor Estivill, de larga tradición en la impresión de literatura popular en Barcelona. ${ }^{80}$ La difusión y tirada de

${ }^{79}$ Castells, Irene: «La resistencia liberal contra el absolutismo fernandino (1814-1833)», Ayer, $\mathrm{n}^{\circ} 41$ (2001), p. 49.

${ }^{80}$ Vilanova, Josep: Auca de la Constitució, Secció de Gravats de la Biblioteca de Catalunya. 
esta aleluya fue importante, pues como mínimo se hicieron dos impresiones diferentes de ella (una de ellas coloreada), llegando su difusión hasta Madrid. La aleluya es una imagen historiada o narrativa, éstas y las imágenes caricaturescas fueron la mejor forma de generalizar los temas políticos entre los sectores populares. Como afirma Burke, ${ }^{81}$ estas formas visuales son los precedentes más inmediatos de la televisión, y permitieron romper el monopolio político de la cultura de las clases dominantes, favoreciendo enormemente el debate político entre los estratos sociales más bajos. De esta manera, en la génesis de la discusión política de las masas populares encontramos estas fórmulas de difusión de ideas a través de formas propias de la cultura popular, la cual se politiza adoptando algunos principios universales del liberalismo.

Volviendo a la aleluya impresa por Estivill, está conformada de ocho filas de viñetas y cada una de ellas se divide en seis viñetas, en total cuarenta y ocho casillas. El formato de aleluya o auca fue muy usado para ilustrar temas de la cultura popular. Un ejemplo lo encontramos en la misma imprenta que ese año, 1822, daba a luz una aleluya con uno de los más típicos motivos de cultura popular de Antiguo Régimen, las llamadas representaciones del Mundo al revés. ${ }^{82}$ Estas aleluyas tenían un significado polisémico pero en ellos se constataban la voluntad de cuestionar el ordenamiento social del Antiguo Régimen. ${ }^{83}$ La potencialidad subversiva de estas imágenes y de las fiestas carnavalescas como fenómenos de inversión social era elevadísima, por eso las autoridades siempre intentaron controlar y encauzar todas estas manifestaciones. Tal y como afirma Burke, ${ }^{84}$ los ilustrados españoles desde la segunda mitad del siglo XVIII habrían intentado reformar la cultura popular, para poder integrar en ella los nuevos valores de la Ilustración. El liberalismo optará por aprovechar los canales de distribución de la cultura popular y los formatos clásicos de la cultura popular, la llamada subliteratura, para facilitar la extensión de la propaganda liberal entre los sectores mayoritarios de la población. Estos eran los sectores menos alfabetizados y los analfabetos, que incrementaban de esta manera su conciencia política. El impacto en la cultura popular de las ideas liberales será fortísimo, hecho que revertirá en la construcción de un nuevo discurso liberal desde abajo con las ideas proporcionadas por el liberalismo, generando así una misma cultura política pero con distintos significados ideológicos.

Las celebraciones de los carnavales intentaron ser controladas por las autoridades liberales en Barcelona. Se prohibieron ${ }^{85}$ los bailes de máscaras y disfraces en la calle, teniendo que recluirse en espacios cerrados. De esta manera se intentaba atajar cualquier

\footnotetext{
${ }^{81}$ Burke, Peter: Visto y no visto, el uso de la imagen como documento histórico..., p. 100.

${ }^{82}$ Galí Boadella, Montserrat: Imatges de la Memòria..., p. 160.

${ }^{83}$ Burke, Peter: La cultura popular en la Europa Moderna, Alianza Editorial, Madrid, 1996, p. 274.

84 Ídem, p. 342.

${ }^{85}$ Yamamichi, Yoshiko: «Fiestas y celebraciones cívico-religiosas en la Barcelona Constitucional...»
} 
posible alboroto popular y evitar que el alto clima de tensión política pudiera desencadenar en un tumulto popular. Paradójicamente, y a pesar de la suspensión de las fiestas de carnaval en el año 1822 a finales de febrero (poco después del fin del Carnaval), se produjo un movimiento de protesta que a punto estuvo de degenerar en revuelta urbana consecuencia del encarcelamiento del comandante de la Milicia, José Costa. Esto nos corrobora una afirmación de Burke ${ }^{86}$ en que insiste en la imbricación entre determinados ritos festivos y los rituales de insurrección popular, permitiendo pasar de la fiesta a la revuelta con una extraordinaria naturalidad. Entre los sectores populares habrá quienes consideren los hechos revolucionarios como una manifestación más de un auténtico carnaval. ${ }^{87}$ Por eso mismo, el hecho que se publicase la aleluya de El Mundo al Revés en el mismo formato y el mismo año que la aleluya Constitucional nos ejemplificaría la voluntad de establecer una comunicación entre la inversión del orden social y el surgimiento de las nuevas ideas liberales. La voluntad de recuperar la tradición de cuestionamiento del orden social justamente durante el Trienio, después que los ilustrados hubieran querido postrarla, nos ofrece un punto de unión entre las ideas de subversión del orden estamental y la concepción de igualdad del liberalismo, emergiendo una nueva sociedad sin clases. ${ }^{88}$

Centrémonos en el análisis del contenido de la aleluya Constitucional. La primera casilla está dedicada a la Constitución asociada al mito solar de la Revolución. La siguiente es una de las fundamentales, pues hace referencia a la reunión de la Nación para elaborar la Constitución. Por consiguiente, la fecha de nacimiento del régimen liberal no se situaría ni en el día de la promulgación de la Constitución de 1812 ni, tampoco, en el alzamiento el dos de mayo de 1808 del pueblo madrileño contra el invasor. El hito fundacional es la reunión de la Nación, en septiembre de 1810, encarnada por sus representantes. Estamos frente al nacimiento de la Nación liberal española, la cual no se remonta a pasados lejanos para legitimar la acción de los liberales españoles. La tercera casilla se ocupa de la promulgación de la Constitución, el 19 de marzo de 1812 en Cádiz. Las siguientes se centran en el juramento de la Constitución por una alegoría que representa a España, el compromiso de defender la religión y todas las ventajas de las que disfrutará el pueblo español por haber promulgado la Constitución, obteniendo de esta forma la felicidad anhelada.

En la viñeta trece observamos el regreso del monarca y cómo éste resulta mal aconsejado, provocando el final de los liberales o patriotas. El triunfo de los serviles o

${ }^{86}$ Burke, Peter: La cultura popular en la Europa Moderna..., p. 286.

${ }^{87}$ Indicador Catalán, $n^{\circ} 234,1$ de octubre de 1822, p. 2: «Barcelona 30 de setiembre. Los tunantes, que se han levantado a mayores y constituídose en regencia de España en Urgell, acaban de procuramos a los patriotas de Barcelona un verdadero día de Carnaval, con su gaceta de dios y el rey».

${ }^{88}$ Romeo Mateo, María Cruz: Entre el orden y la revolución..., p. 95. 
absolutistas inevitablemente comporta la represión de los liberales. De esa forma, usando la fórmula tradicional del mal consejo, se consigue desresponsabilizar la figura del monarca y cargar las culpas en sus ministros, sin que la involución política esté vinculada al rey. Desde el primer momento, se suceden los intentos de restablecimiento del régimen liberal, encabezados por Espoz y Mina, por Porlier o por Lacy. El fracaso de todos ellos lo contemplamos con las ejecuciones de Porlier y Lacy. La conspiración de Lacy por haberse producido en Cataluña y por sus fuertes imbricaciones con la sociedad catalana es narrada detalladamente, dedicándole un total de seis viñetas.

Las seis siguientes casillas (de la 25 a la 31) reproducen los hitos más destacados del pronunciamiento de Riego, hasta que el monarca jura la Constitución, reconciliándose así con los liberales. Se omite la proclamación de la Constitución por parte de Riego, siendo Quiroga el primero en aparecer proclamándola el 8 de enero de 1820, pero la imagen deja bien claro que el artífice del triunfo de la sublevación revolucionaria fue Riego. Sin omitir el hecho que Quiroga era el militar de mayor rango y por lo tanto cabecilla de la Revolución, la gloria de la historia estaba reservada para el héroe romántico español, Riego, quien con sus acciones fue el auténtico líder de la Revolución. Una vez más, nos encontramos frente a un magnífico ejemplo de Romanticismo popular. De nuevo el rey es aconsejado por sus ministros, pero en esta ocasión su consejero Francisco Ballesteros le sugiere que jure la Constitución. El día 9 de marzo de 1820 el rey juró la Constitución, esta es una imagen insólita, pues las primeras imágenes del juramento por parte del monarca no las obtendremos hasta después del 9 de julio de 1820 , fecha en la que el rey juró la Constitución en las Cortes. Desde el 9 de marzo al 9 de julio de 1820 , se intentaron evitar todas las posibles vinculaciones visuales del monarca con la Constitución, no habiendo así ninguna imagen que represente la asunción de la Constitución por parte del monarca. Simplemente, se conserva un boceto de litografía en la que aparecía el rey acatando y jurando la Constitución. La nula presencia de imágenes del primer juramento real nos hace pensar que el dibujante de esa casilla reprodujo lo ocurrido a partir de un modelo, y éste sería la aceptación en Barcelona de la Constitución por parte del Capitán General Castaños, cuando salió al balcón de la Lonja alzando un libro con una de sus manos, simbolizando de esta manera el juramento de la Constitución.

El triunfo liberal es visible mediante el laurel que sujeta en una de sus manos la figura clásica que simboliza a España. La victoria supone el fin de los serviles y de la gran institución represora del Antiguo Régimen, la Inquisición. La imagen a la cual se recurre para ejemplificar su fin es la liberación de los presos de las mazmorras inquisitoriales. No aparece ninguna referencia clara que nos permita identificar la ciudad donde se produce la liberación de los presos de la Inquisición, sugiriendo de esta forma la idea de fin y destrucción de la institución, y no de un asalto puntual en una u otra ciudad, 
legitimando así todos los tumultos que en esos primeros días de la revolución comportaron el asalto al tribunal en ciudades como Madrid, Valencia, Barcelona, etc. Las casillas 34 y 35 hacen referencia a los nuevos mártires de la libertad, el primero es un colectivo, el pueblo de Cádiz, y el segundo un individuo, Acevedo. Finalmente, la entrada triunfal de Riego en Sevilla pone fin a las dudas sobre el establecimiento del régimen liberal.

Las siguientes casillas corresponden a los hechos más destacados del año 1820, entre ellos los más significativos son las sumisión de Riego y sus correligionarios al rey, la liberación y nombramiento de Canga Argüelles como miembro del gobierno, y la glorificación de los restos de Lacy. Las últimas casillas son todas referencias simbólicas a los héroes de la revolución del año 1820. Las cuatro primeras corresponden a los inmortales cabecillas del pronunciamiento, pero con la novedad de no aparecer López Baños, y su lugar ser ocupado por Villacampa, y es muy posible que este cambio se debiera al carácter moderado del primero y a la popularidad barcelonesa del segundo, ya que en 1820 fue el militar escogido por el pueblo para ocupar la capitanía general de Cataluña. La relevancia de Riego entre los sectores populares puede verse reflejada en esta aleluya, pues su imagen protagoniza cuatro de las viñetas, siendo el héroe del pronunciamiento que se recrea en más ocasiones. Sus compañeros Quiroga y Arco Agüero protagonizan sólo dos viñetas cada uno, siendo la excepción López Baños, quien no aparece en la aleluya. El culto al héroe, Riego, sólo es superado por el culto al héroe muerto, al mártir Lacy, ya que su particular «vía crucis» es narrado a lo largo de ocho viñetas. Las tres últimas casillas se hacen eco de la gloria con que era venerado el colectivo miliciano, encarnación de la ciudadanía, obviando el ejército. Puede que ésta fuera una forma de sublimar la imposibilidad de representar el gran líder del radicalismo liberal barcelonés, el ex-comandante de la milicia de la ciudad, José Costa, uno de los dirigentes con más calado entre las masas populares, preso desde febrero de 1822.

Para designar la figura del rey en la aleluya, Fernando VII, se utiliza una banda que cruza su pecho. Este distintivo nos indicaría cómo los sectores populares reconocían al monarca no por sus facciones sino por sus atuendos. Esta conclusión revela la tremenda importancia que tuvo la litografía de Cardona (1823) a partir de un dibujo de Lacoma, ${ }^{89}$ donde el monarca se presentaba sin ninguno de los distintivos que daban fe de su dignidad real. Esta fue la primera representación del monarca burgués y burócrata alejado de las características de la realeza de Antiguo Régimen. La litografía, pues, sería un precedente de la posterior representación en Francia del monarca Luis Felipe.

- La última de las imágenes (imágenes 4 y 5) que analizaremos son las presentes en un juego de naipes publicado por la imprenta de Simón Ardit en 1822, dedicado a

\footnotetext{
${ }^{89}$ Vega, Jesusa: Origen de la litografía en España. Real Establecimiento litográfico..., p. 72.
} 
la Junta de Comercio de Barcelona. ${ }^{90}$ De todas las cartas de la baraja española, nos circunscribiremos al análisis de las más significativas, sotas, caballos, reyes y los ases de la baraja. Las cuatro sotas corresponden a los mártires de la revolución española. Entre el martirologio liberal se escoge a los siguientes: Daoíz, Velarde, Lacy y Porlier. Su elección condiciona la lectura del discurso político liberal que se pretende difundir, una lectura que explícitamente vincula la génesis del liberalismo con la lucha contra el invasor francés. Otras posibles elecciones hubieran permitido enfatizar el carácter liberal de los mártires, como por ejemplo, si en lugar de los dos primeros se hubieran escogido a alguno de los liberales muertos gloriosamente durante el sexenio absolutista, como Acevedo, Sánchez Barbero, Mina... Si por el contrario, la finalidad hubiera sido subrayar la lucha por la libertad a lo largo de la historia de España, probablemente fuera más coherente haber incluido dentro del grupo de mártires a Comuneros o Aragoneses. La glorificación de la lucha contra el invasor francés aglutina a todo el conjunto del liberalismo, pero la exaltación de la lucha diluye la percepción del proceso revolucionario desarrollado a posteriori. Por lo tanto, se minimizan los efectos de la Revolución, valorando simplemente el hecho puntual de la sublevación del pueblo de Madrid.

Los cuatro caballos de la baraja corresponden a los cuatro héroes del pronunciamiento de 1820. La representación ecuestre de los héroes, evoca un tema clásico como era el gobernante montando y dirigiendo la Nación. La elección de los inmortales, los cuatro cabecillas del Ejército de la Isla, parece lógica, pero cabe tener presente que en esas fechas ya era bien conocida la muerte de uno de ellos, y por lo tanto el grupo ya no era completo. En consecuencia, el mantenimiento del cuarteto respondería a la voluntad de mantener por encima de todo el espíritu del pronunciamiento de 1820 , evitando toda posible deriva revolucionaria con la consiguiente fractura social. Recordemos que de los cuatro héroes dos eran fervientes defensores de posiciones moderadas, uno estaba muerto y el otro, Riego, se encontraba en 1822 en el momento de máximo respaldo popular, y en consecuencia, incluirlo con los otros cuatro era difuminar su liderazgo. Incluir a Riego en el grupo de los cuatro era olvidar su primacía al frente del movimiento exaltado y su liderazgo entre los sectores populares.

Los cuatro ases nos muestran los pilares en los que se sustentaba el liberalismo, básicamente, la división de poderes. El as del palo de la Constitución regiría el poder legislativo. El as del palo de la Justicia preservaría el poder ejecutivo, y los otros dos ases corresponderían el palo de la Fuerza, encarnado, por la milicia y el ejército, y por último, el del palo de la Unión, que integraría al conjunto de la nación española. Los cuatro reyes son representados mediante leones coronados, cada uno de los cuatro aludiendo a una de las ideas matrices del liberalismo, la Constitución, la lucha contra

${ }^{90}$ Soldevila, Ferran: Historia dels Catalans, Vol. 5, Edicions Ariel, Barcelona, 1970, pp. 2536-2537. 
el despotismo y la esclavitud, la nueva legalidad constitucional (ejemplificada con el código civil y el código penal) y el último de ellos solicitaría la unión de toda la Nación para vencer a los privilegiados.

Todos los elementos citados nos acercan a una lectura del liberalismo muy cerrada impidiendo cualquier posibilidad de apelar a principios universalistas que permitieran una alternativa política radical. La lectura política es suficientemente conducida por el autor de la baraja para no inducir a reinterpretaciones revolucionarias. Esta voluntad de no desviarse del nuevo orden nacido con el régimen liberal pondrá las bases de lo que posteriormente fue el liberalismo moderado. 


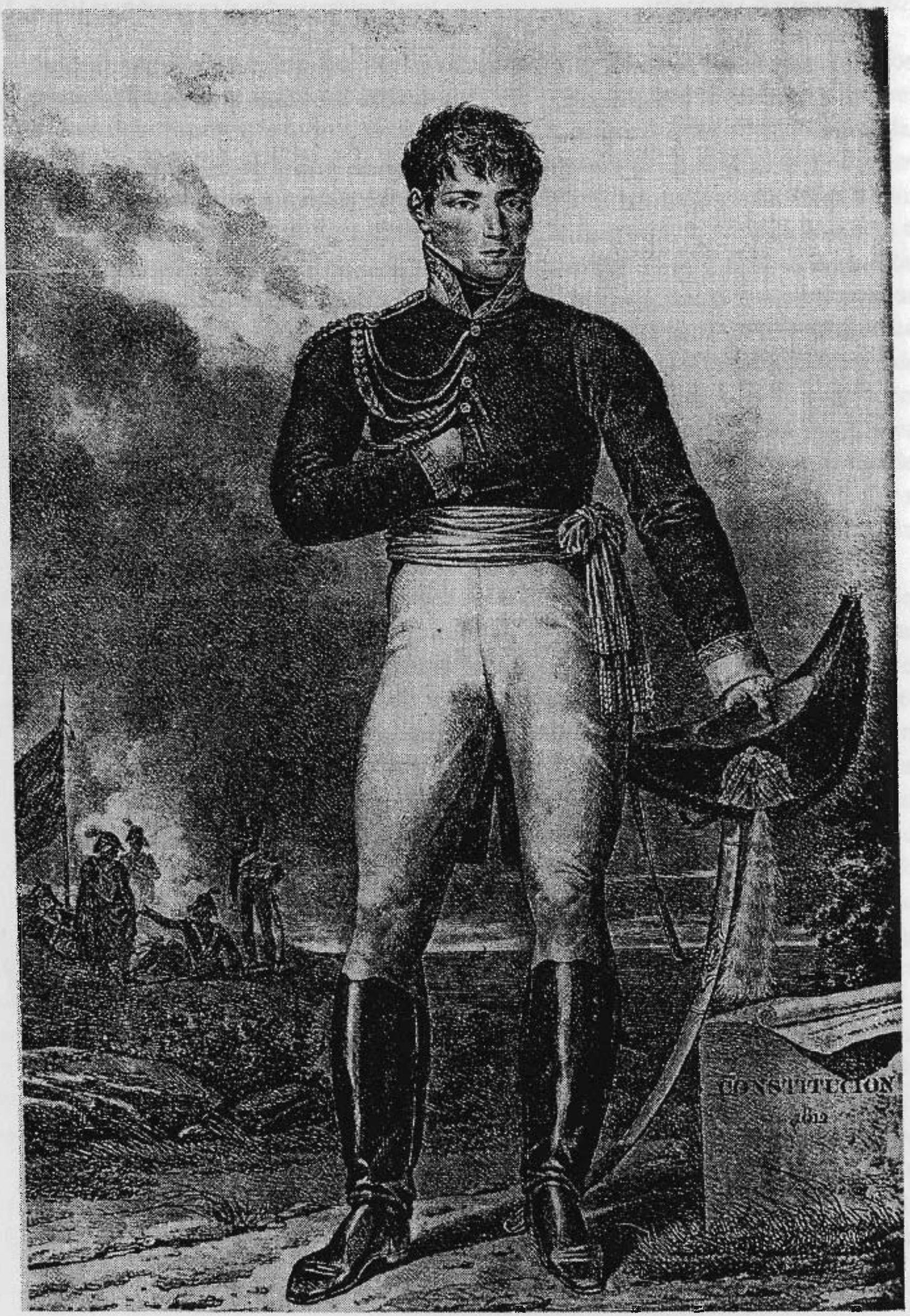

Imagen 1: Litografia de Riego por G. Engelmann. 


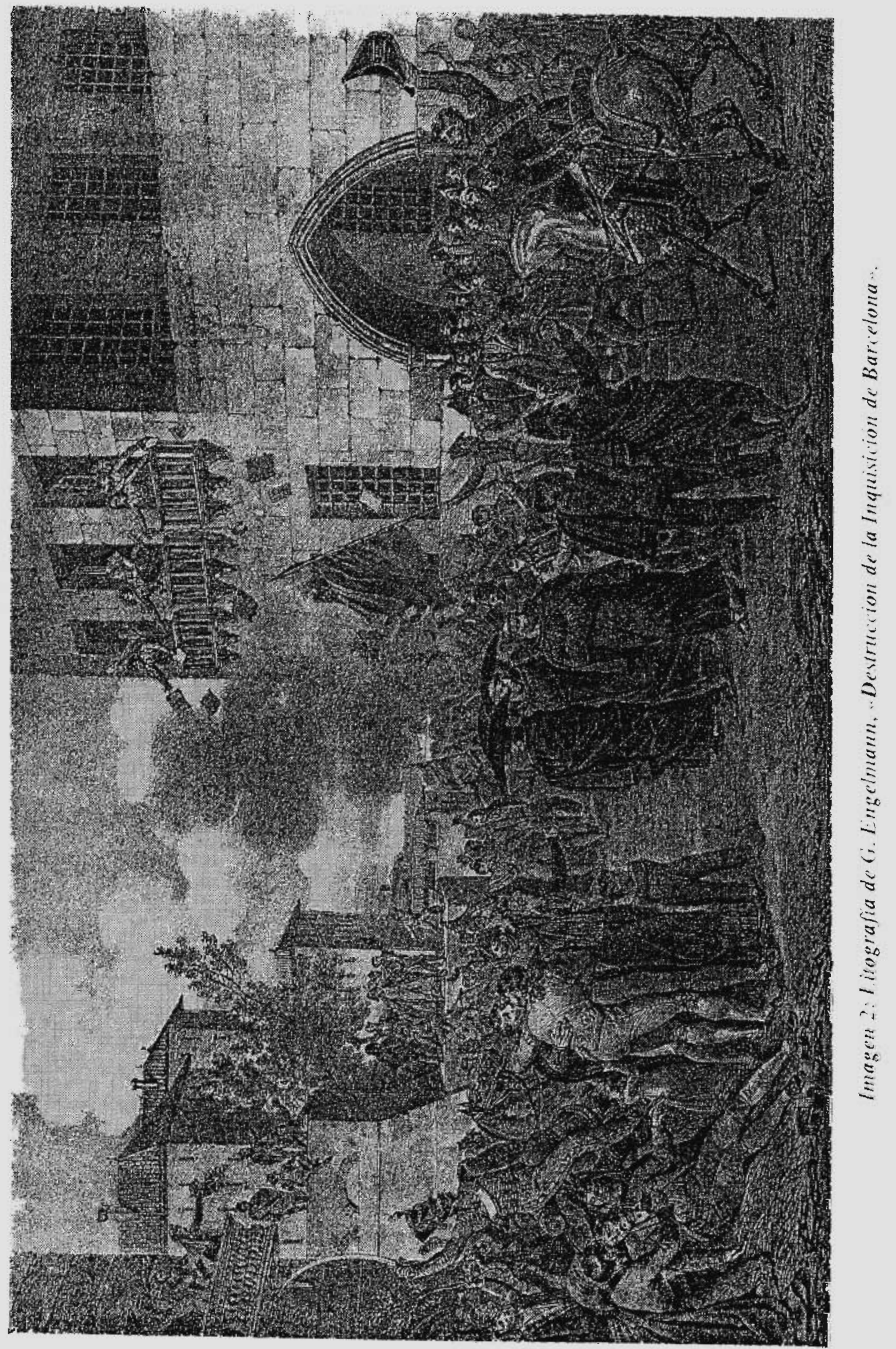




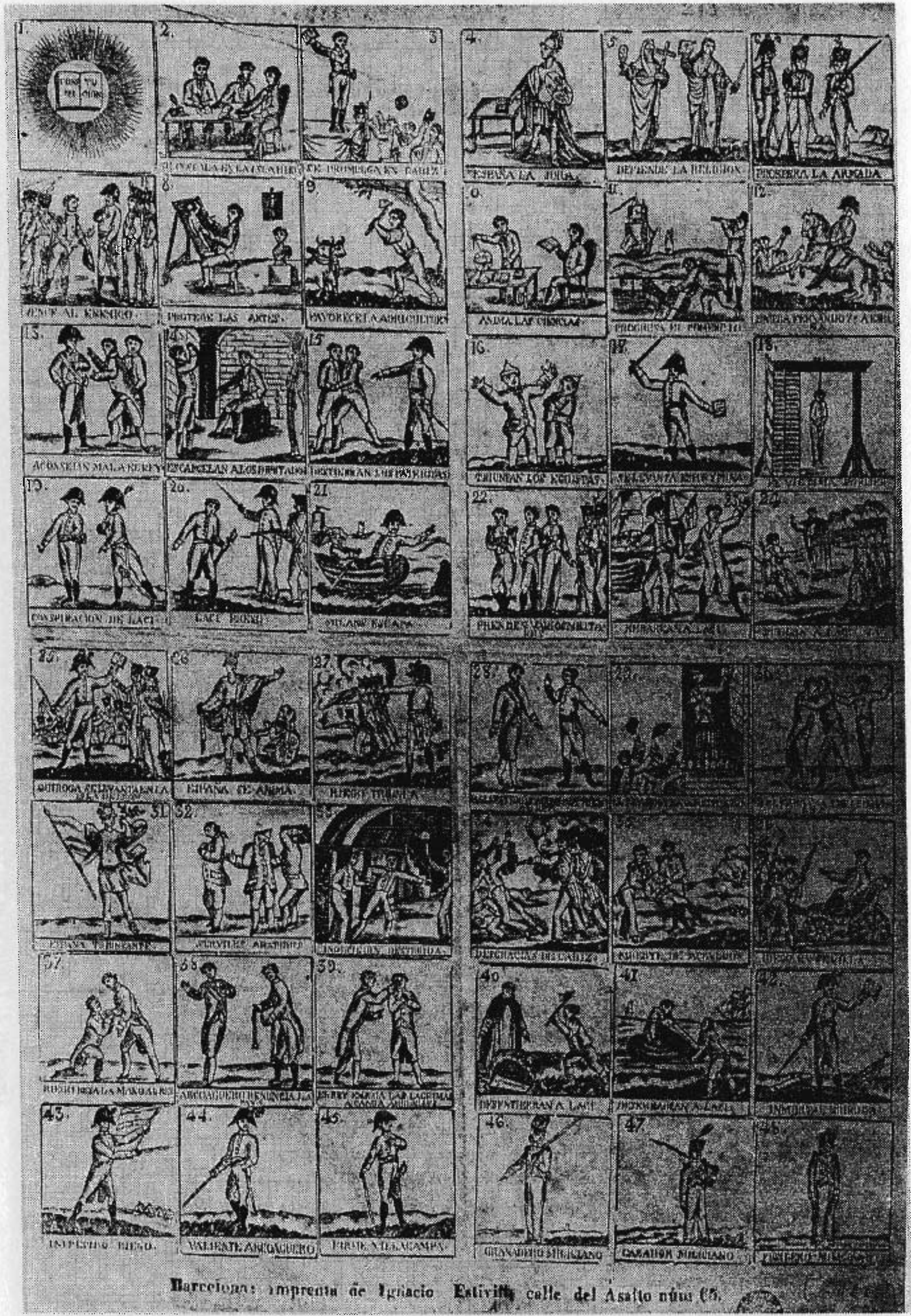




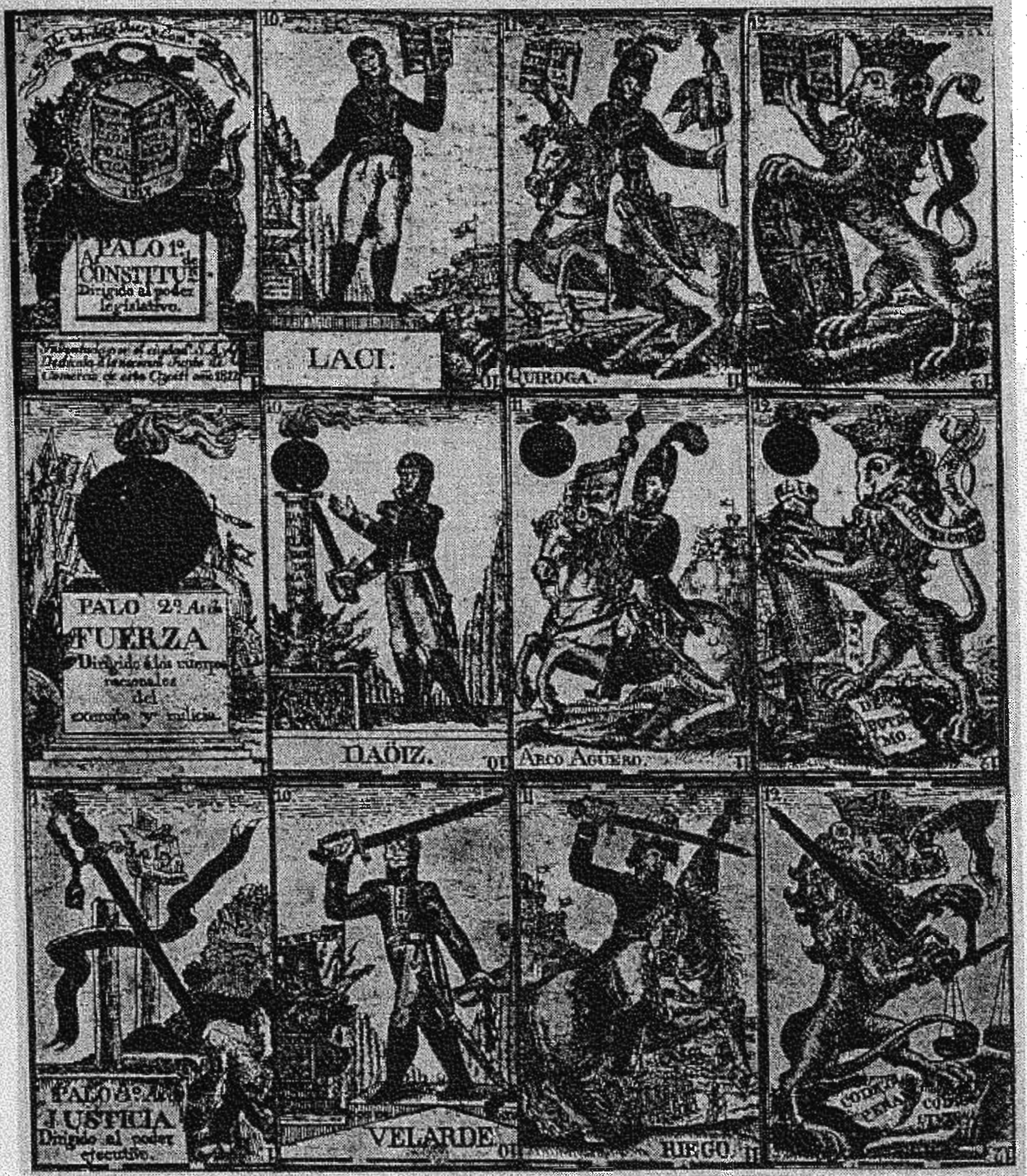

Imagen 4: Baraja de la constitución (I). 


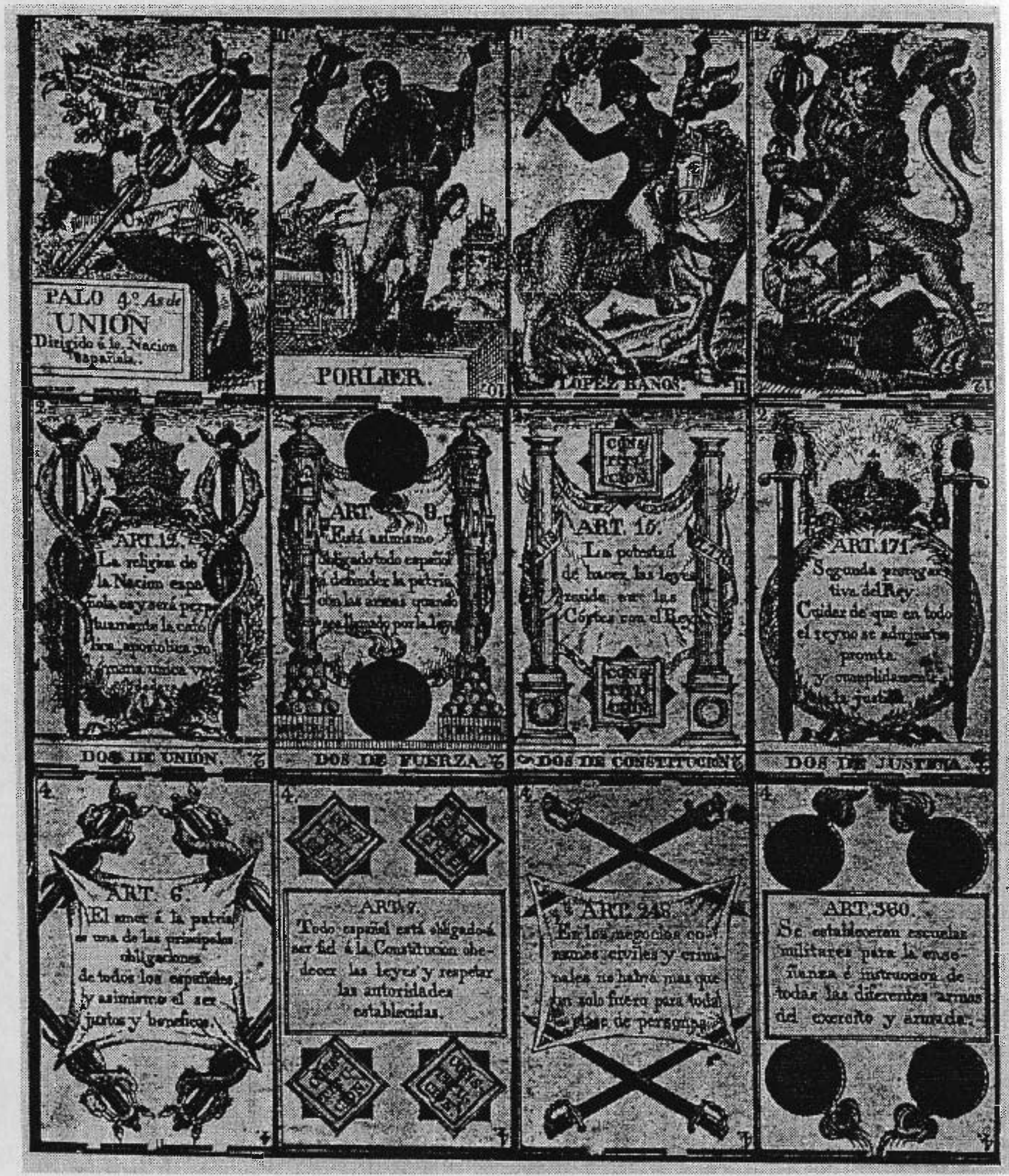

Imagen 5: Baraja de la constitución (II). 